\title{
Illustrations and studies in Neotropical Orchidaceae. 6. The Lepanthes guatemalensis group (Pleurothallidinae) in Costa Rica
}

\author{
Franco Pupulin ${ }^{1,2,3^{*}} \&$ Diego Bogarín ${ }^{1,4}$ \\ ${ }^{1}$ Jardín Botánico Lankester, Universidad de Costa Rica. P.O. Box 302-7050 Cartago, Costa Rica, A.C. \\ ${ }^{2}$ Harvard University Herbaria, 22 Divinity Avenue, Cambridge, Massachusetts, U.S.A. \\ ${ }^{3}$ Marie Selby Botanical Gardens, Sarasota, FL, U.S.A. \\ 4"Ángel Andreetta” Andean Orchids Research Center, University Alfredo Pérez Guerrero, Ecuador. \\ franco.pupulin@ucr.ac.cr
}

\begin{abstract}
Pupulin, F. \& Bogarín, D. 2014. Illustrations and studies in Neotropical Orchidaceae. 6. The Lepanthes guatemalensis group (Pleurothallidinae) in Costa Rica. Anales Jard. Bot. Madrid 71(1): e001.

We revise and characterize the group of species close to Lepanthes guatemalensis. The group comprises eight species in Costa Rica. Three new species are described and illustrated. Lepanthes durikäensis is distinguished by the non resupinate flowers, the lateral sepals ovate with the apical tails diverging, the lower lobe of petals lanceolate-subfalcate, up-curved and the pinkish column. Lepanthes leporina is recognized by the resupinate flowers with yellow sepals, faintly suffused with red, the petals violet, the lip orange, the bifid synsepal with the apices of the lateral sepals not forming tails, the lateral sepals subequal to the dorsal sepal, the petals markedly convex with the upper lobe elliptic-lanceolate and the lobes of the lip connivent at apex. Lepanthes sanctiorum is characterized by the small plants less than $1.1 \mathrm{~cm}$ tall, the short peduncle less than $10 \mathrm{~mm}$ long, the petals as wide as the lip length and the blades of the lip distinctly diverging at apex. All the species are described and illustrated on the basis of Costa Rican material. A key to the species of the group is provided.
\end{abstract}

Keywords: Lepanthes durikäensis, L. edwardsii, L. guanacastensis, L. leporina, L. ruberrima, L. sanctiorum, L. schugii, L. tapantiensis, new species, taxonomy.

\section{INTRODUCTION}

Species of the large genus Lepanthes Sw. have proven to be difficult to arrange into smaller taxonomic units. Apart from a quite general vegetative architecture, composed by monophyllous (rarely prolific) secondary stems, or ramicauls, covered with "lepanthiform" sheaths, mostly distally dilated and variously ciliate, and congested, distichous inflorescences, Lepanthes present any conceivable arrangement of the floral parts, with a continuum of variation between the most distinctive morphological schemes.

Luer (1986) proposed to divide Lepanthes into four subgenera, subgen. Brachycladium, now elevated at the generic rank as Neooreophilus Archila [syn. Brachycladium (Luer) Luer, Oreophilus W.E.Higgins \& Archila, Penducella Luer \& Thoerle)], Draconanthes, now ranked at generic level as Draconanthes (Luer) Luer (1996), Marsipanthes, and Lepanthes, mainly distinguished by several characters of the petals and the lip. Within the most diverse subgenus Lepanthes, he recognized two sections, sect. Lepanthes and Haplocheilus, the latter distinguished by the membranous

\section{Resumen}

Pupulin, F. \& Bogarín, D. 2014. Ilustraciones y estudios en Orchidaceae neotropicales. 6. El grupo Lepanthes guatemalensis (Pleurothallidinae) en Costa Rica. Anales Jard. Bot. Madrid 71(1): e001.

Revisamos y caracterizamos el grupo de especies cercanas a Lepanthes guatemalensis. El grupo está compuesto por ocho especies en Costa Rica. Se describen e ilustran tres especies nuevas. Lepanthes durikäensis se caracteriza por las flores no resupinadas, los sépalos laterales ovados, con las colas apicales divergentes, el lóbulo inferior de los pétalos lanceolado-subfalcado, con curvatura hacia arriba y la columna rosada. Lepanthes leporina es reconocida por las flores resupinadas, los sépalos amarillos y ligeramente teñidos de rojo, los pétalos violeta, el labelo naranja, el sinsépalo bífido con los ápices de los sépalos laterales que no forman colas, los sépalos laterales subiguales al sépalo dorsal, los pétalos marcadamente convexo con el lóbulo superior elíptico-lanceolado y los lóbulos del labelo conniventes en el ápice. Lepanthes sanctiorum se caracteriza por las plantas pequeñas menores a $1,1 \mathrm{~cm}$ de largo, el pedúnculo corto menor a $10 \mathrm{~mm}$ de largo, los pétalos tan anchos como la longitud del labelo y las láminas del labelo claramente divergentes en el ápice. Todas las especies se describen e ilustran basadas en material de Costa Rica. Se presenta una clave para las especies del grupo.

Palabras clave: Lepanthes durikäensis, L. edwardsii, L. guanacastensis, L. leporina, L. ruberrima, L. sanctiorum, L. schugii, L. tapantiensis, especies nuevas, taxonomía.

petals and lip (Luer, 1986). However, even with the transfer of a relatively small number of taxa to sect. Haplocheilus, the large majority of Lepanthes still remain in subgen. Lepanthes sect. Lepanthes. This section constitutes a mostly Andean group including over 700 species provided with lobed lip, the lateral lobes modified into blades and the mid-lobe, if present, modified into an appendix (Luer, 1996).

The fact that most species of Lepanthes were described in the framework of floristic studies, with little or no interest directed toward a phylogenetic context, often without any reference to interspecific relationships, makes more difficult to recognize groups of closely related taxa, which probably share common, recent evolutionary histories. Nevertheless, as a part of a series of studies aimed to produce a complete taxonomic revision of the subtribe Pleurothallidinae for Flora Costaricensis, we are trying to informally circumscribe, characterize and illustrate discrete groups of species, which share common sets of vegetative and floral features, to facilitate their comparative study and a full appreciation of groups' diversity. Here we discuss a group of species quite atypical in the flora of Mesoamerica by the very small plants provided

\footnotetext{
* Corresponding author.
} 
with successive inflorescences distinctly longer than the leaves, proportionally large flowers, the sepals mostly caudate, the blades of the lip narrow and long, and a characteristic, helmet-shaped, apically deeply bilobed anther cap (Fig. 1). Even though it is not restricted to Central America, the group is apparently most diverse north to the Panamanian isthmus.

The Colombian painter Francisco Javier Matis Mahecha (1774-1851), who worked for the Real Expedición Botánica del Nuevo Reino de Grenada lead by Mutis from 1783 until 1816, illustrated the first species of Lepanthes of this group in 1803 (Mutis, Drawings of the Royal Botanical Expedition to the new Kingdom of Granada, t. 339A, Real Jardín Botánico de Madrid) (Fig. 2). His delicate tempera was eventually published only in 1969, when C. Schweinfurth identified it as Lepanthes costata (Mutis, 1969), and it was not until 2010 when Lisa Thoerle and Father Pedro Ortiz recognized the
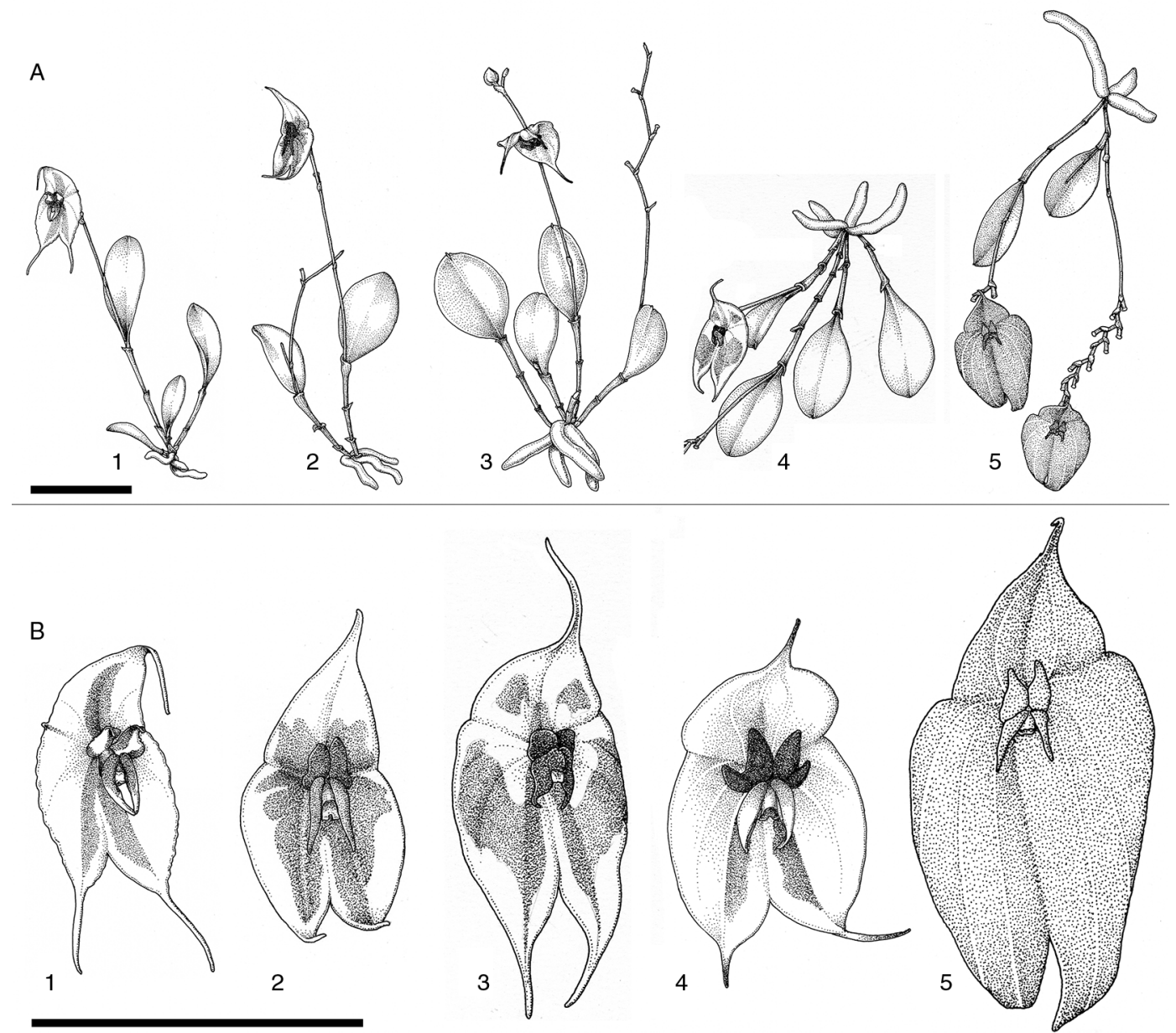

C
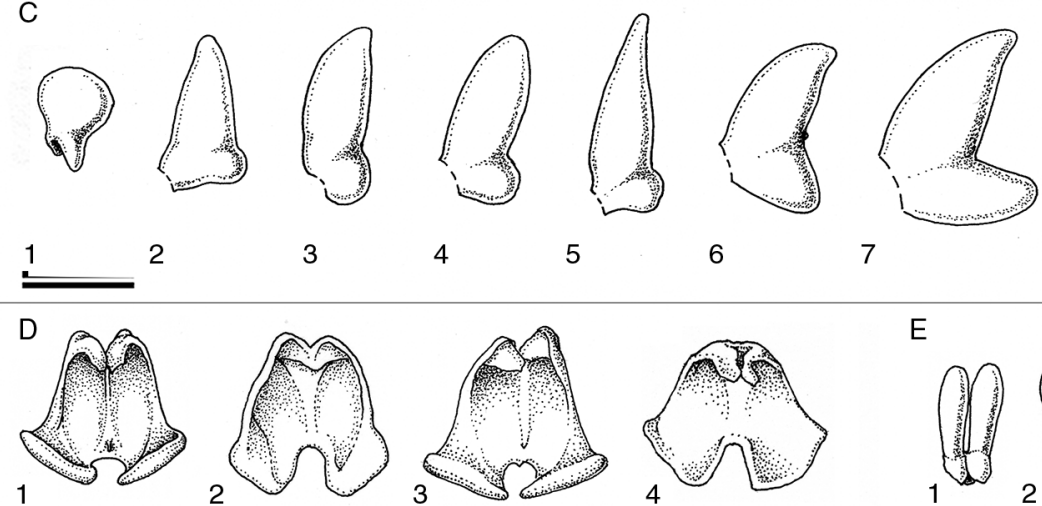

3

4

5

6

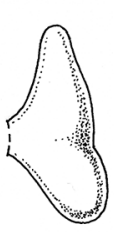

8
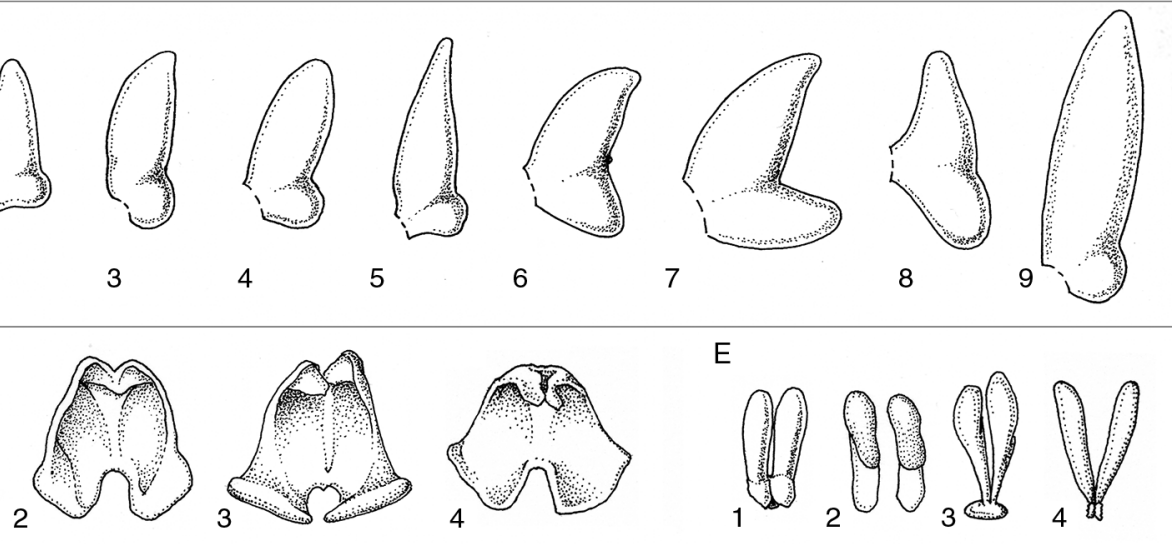

$\mathrm{E}$

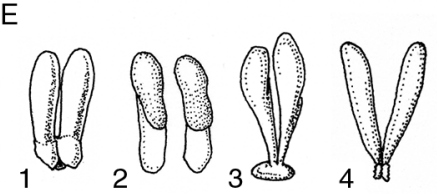

Fig. 1. Vegetative and floral morphology of Lepanthes species of the L. guatemalensis group: a, plant habit; 1, L. tapantiensis; 2, L. schugii; 3, L. durikäensis; 4, L. guanacastensis; 5, L. ruberrima; b, flowers; 1, L. tapantiensis; 2, L. schugii; 3, L. guanacastensis; 4, L. durikäensis; 5, L. ruberrima; c, petals; 1, L. guanacastensis; 2, L. sanctiorum subsp. gravida; 3, L. schugii; 4, L. sanctiorum subsp. sanctiorum; 5, L. edwardsii; 6, L. tapantiensis; 7, L. durikäensis; 8, L. ruberrima; 9, L. leporina; d, Anther cap: 1, L. tapantiensis; 2, L. schugii; 3, L. durikäensis; 4, L. sanctiorum; e, pollinarium; 1, L. tapantiensis; 2, L. schugii; 3 , L. durikäensis; 4, L. sanctiorum (autogamous form). Scale bars $=1 \mathrm{~cm}$; double bars $=1 \mathrm{~mm}$. Drawn by the authors from fresh material. 


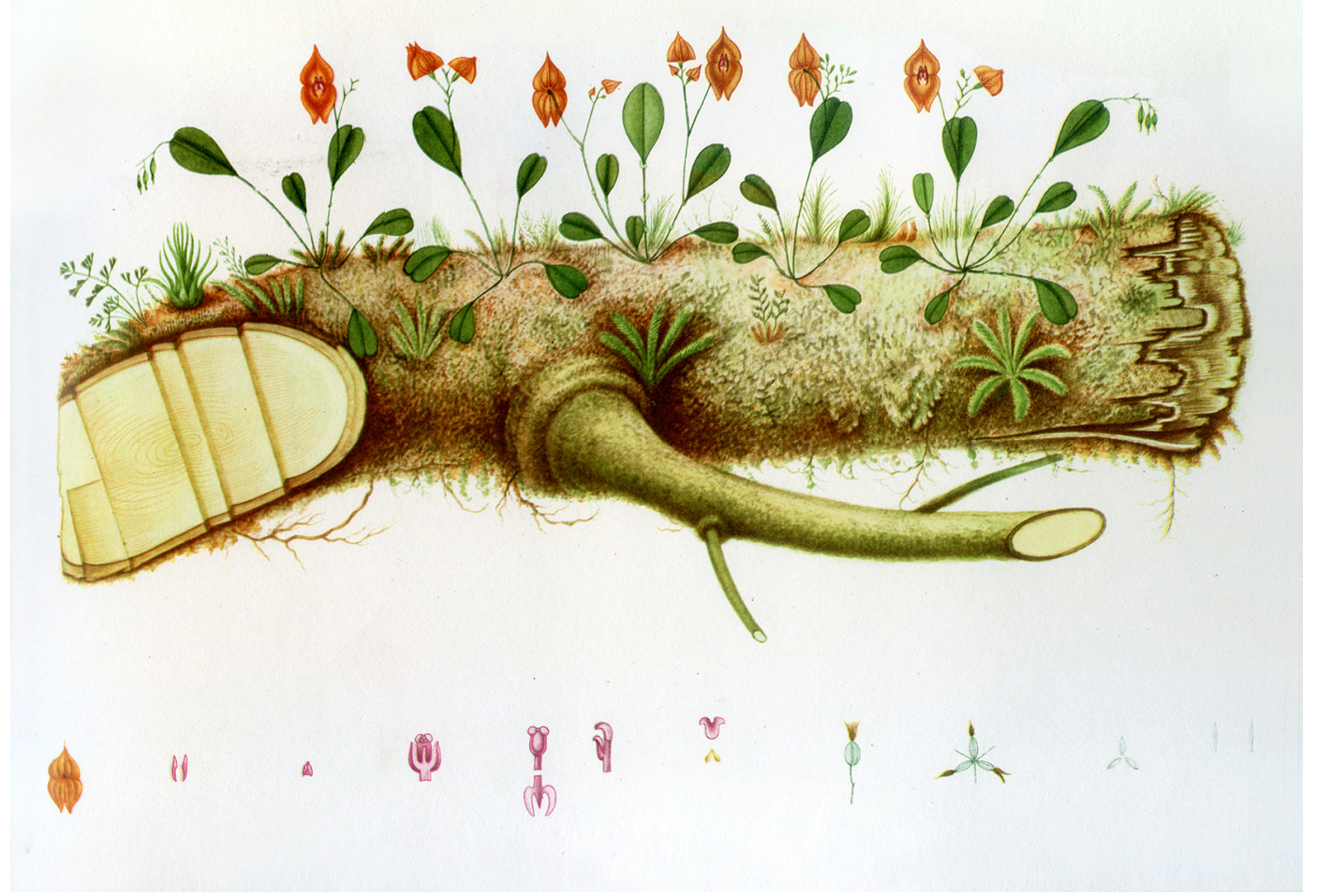

Fig. 2. Lepanthes matisii, the first species of this group to be illustrated by F. J. Matis Mahecha in 1803.

plant painted by Matis as a distinct taxon, describing it as Lepanthes matisii in honour to the artist who first illustrated it (Thoerle, 2010). It is noteworthy that Matis accurately depicted the long-caudate lip and the small, deeply bilobed anther cap, which are distinctive of the group.

It was Rudolf Schlechter who simultaneously described the first two Mesoamerican species belonging to this group of Lepanthes, based on Guatemalan collections by Hans Freiherr von Türckheim (1853-1920) from the area of Cobán in Alta Verapaz (Schlechter, 1912). Lepanthes guatemalensis Schltr. (Schlechter, 1912:355) was compared with L. horrida Rchb.f. (which pertains to a different group) and separated by the distinctly lax inflorescence that greatly surpasses the leaf, and the golden yellow flowers. The species ranges from Chiapas, in southern Mexico, to El Salvador (Hamer 1988). Lepanthes tuerckheimii Schltr. (Schlechter, 1912:357) was described on the basis of three collections by Türckheim, the first of which made in November 1877, a few months after the German Baron arrived in Guatemala, and the last one thirty years after, in 1907. Schlechter considered it closely related to his L. guatemalensis and to L. horrida, and described the color of the flowers as dark magenta. According to Ames \& Correll (1952), Salazar Chávez \& Soto Arenas (1996), and Hágsater \& Soto Arenas (2003), L. tuerckheimii is a synonym of L. guatemalensis. In his revision of Lepanthes in Guatemala, Archila M. (2001) considered it a natural hybrid between L. verapazensis Archila and L. guatemalensis.

In 1923, O. Ames used another collection by Türckheim (Guatemala. Alta Verapaz: Ainal, 4500 pp., Jul. 1886, H. von
Tuerckheim 967) to describe L. gibberosa. Ames compared his new species to L. guatemalensis from which it supposedly differs by the lateral sepals "being protuberant on the inner margin near the base of a caudate tip" (Ames, 1923). The drawing of the type at AMES leaves no doubts that this name is a synonym of $L$. guatemalensis.

The goal of this article is to revise and characterize the group of species close to Lepanthes guatemalensis. The group comprises eight species in Costa Rica. We describe three species based on Costa Rican material. A key to the species of the group is provided. Additional material is provided online at www.epidendra.org (Pupulin, 2007).

\section{Taxonomic treatment}

KEY TO THE SPECIES OF THE LEPANTHES GUATEMALENSIS GROUP IN COSTA RICA

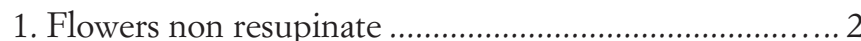

1. Flowers resupinate ……............................................. 3

2. Lateral sepals elliptic, the tails straight to curved inward; lower lobe of petals rounded ....................... L. edwardsii

2. Lateral sepals ovate, the apical tails diverging; lower lobe of petals lanceolate-subfalcate, up-curved

L. durikäensis

3. Synsepal bifid, the apices of the lateral sepals not forming tails

3. Synsepal caudate, the apices of the lateral sepals forming distinct tails .................................................................. 5 
4. Flowers concolorous purple-red; lateral sepals much longer than dorsal sepal; petals flat, the upper lobe triangular; blades of the lip without connivent apices

L. ruberrima

4. Flowers with yellow sepals, faintly suffused with red, the petals violet, the lip orange; lateral sepals subequal to the dorsal sepal; petals markedly convex, the upper lobe elliptic-lanceolate; blades of the lip with connivent apices

L. leporina

5. Upper lobes of the lip orbicular; blades of the lip sigmoid, with a distinct basal lobe .................... L. guanacastensis

5. Upper lobes of the lip triangular-lanceolate; blades of the

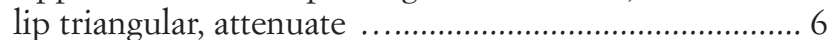

6. Peduncle $<10 \mathrm{~mm}$ long; petals as wide as the lip lenght; blades of the lip distinctly diverging at apex

L. sanctiorum

6. Peduncle $>13 \mathrm{~mm}$ long; petals distinctly narrower than the lip length; blades of the lip subparallel to converging at apex .... 7

7. Basal margins of synsepal wavy-subcrenulate; petals with the upper and lower lobes subequal, with a small mucro in between; blades of the lip incurved-uncinate

L. tapantiensis

7. Basal margins of synsepal plain; lower lobe of petals much smaller, rounded, upper lobe lanceolate, without a mucro; blades of the lip straight to slightly diverging

L. schugii

\section{Description of the species}

Lepanthes durikäensis Bogarín \& Pupulin, sp. nov.

Type: COSTA RICA. Puntarenas: Buenos Aires, Buenos Aires, mountain chain in front to the Cerro Utyum and Cabagra river, Durika Biological Reserve, $9^{\circ} 18^{\prime} 47.97^{\prime \prime} \mathrm{N}$ $83^{\circ} 12^{\prime} 50.09^{\prime \prime} \mathrm{W}, 2418 \mathrm{~m}$, epiphytic, collected by Daniel Jiménez, Eugenio García and Pontus Aratoun, flowered in cultivation at Jardín Botánico Lankester, 25 May 2011, F. Pupulin 8093 (holotype, JBL-spirit). Illustrations: Fig. $3 \mathrm{~A}$ and 4.

Ab Lepanthe edwardsii Ames sepalis lateralibus late ellipticis caudis divergentibus, lobulis infernis petalorum lanceolatisubfalcatis introrsis ad lobos supernos spectantis praecipue recedit.

Epiphytic, small, caespitose, erect herb, to $2 \mathrm{~cm}$ tall. Roots thick, glabrous, 1.6-2.5 $\mathrm{mm}$ in diameter. Ramicauls slender, $0.6-1.3 \mathrm{~cm}$ long, enclosed by $2-3$ glabrous, whitish sheaths. Leaf thinly coriaceous, broadly elliptic, rounded, deeply and narrowly retuse, with a distinct abaxial mucro, $8-11 \mathrm{~mm}$ long, $5-7 \mathrm{~mm}$ wide, shortly cuneate at the base into a petiole about $0.5 \mathrm{~mm}$ long. Inflorescence produced singly, larger than the leaf, a loose, distichous, successively few-flowered (to $5+$ flowers) raceme to $40 \mathrm{~mm}$ long; filiform peduncle to $20 \mathrm{~mm}$ long, provided with 1-2 short tubular, obtuse bracts; rachis fractiflex. Floral bracts broadly ovate, amplectent, subacute, ca. $1 \mathrm{~mm}$ long, $0.7 \mathrm{~mm}$ wide, sparsely muriculate; pedicel $1.5 \mathrm{~mm}$ long, glabrous; ovary $1 \mathrm{~mm}$ long, subtrigonous, the carpels provided with semihyaline, subcrenulate wings. Flowers non resupinate, large for the genus, with pale translucent yellow sepals, suffused with red along the midveins, the petals red, the lateral lobes of the lip yellow with the base orange-red, the column yellow, the anther cap violet. Dorsal sepal ovate, contracted at apex into an acuminate tail ca. $3 \mathrm{~mm}$ long, $8 \mathrm{~mm}$ long including the tail, $4 \mathrm{~mm}$ wide, 5 -veined, connate to the lateral sepals for $2 \mathrm{~mm}$. Lateral sepals ovate-elliptic, connate for about half of their length into a suborbicular synsepal ca. $8 \mathrm{~mm}$ long (including the tails), $7.5 \mathrm{~mm}$ wide, apically contracted into acuminate tails ca. $3 \mathrm{~mm}$ long, connate to the dorsal sepal for $2 \mathrm{~mm}$. Petals transversely bilobed, $2 \mathrm{~mm}$ long, $2.5 \mathrm{~mm}$ wide, the upper lobes lanceolate, subacute, $2 \mathrm{~mm}$ long, $1.2 \mathrm{~mm}$ wide, the lower lobes lanceolate subfalcate, obtuse-subrounded, introrse, curved upward, ca. $1.5 \mathrm{~mm}$ long, $1 \mathrm{~mm}$ wide. Lip bi-laminate, the blades narrowly digitate-falcate, acuminate, $2.5 \mathrm{~mm}$ long, $0.7 \mathrm{~mm}$ wide, adpressed to the column, the connectives trapezoidal, the body thin, rounded-protruding at apex, with a very thin, up-curved, digitate, glabrous appendix. Column short, truncate, $1.5 \mathrm{~mm}$ long, the anther apical, the stigma ventral. Anther cap cucullate, helmetshaped, apically deeply bilobed. Pollinia 2, narrowly lanceolate, on a rounded, flat viscidium.

Etymology: The indigenous word Durika is perhaps derived from the Bribri duli "place of the tree of the high slope" or the Cabécar duleka "vertical", in reference to the steepy mountain. It is named after Cerro Durika at Fundación Reserva Biológica Durika, in southern Talamanca mountain range, where the type plants were collected.

Distribution: Known from the Talamanca mountain range in southern Costa Rica and western Panama.

Habitat: Epiphytic in branches in secondary and primary forest mostly Quercus spp. in premontane wet forest along the Cordillera de Talamanca at around 2000-2205 m of elevation.

\section{Additional material examined (paratypes)}

COSTA RICA-PANAMÁ. Puntarenas-Chiriquí: Coto Brus-Renacimiento, línea fronteriza entre Cerro Quijada del Diablo y Cerro Pando, entre mojones N.336-338, 8 $54^{\prime} 51.9^{\prime \prime}$ N 82 43'59.13" W, $2205 \mathrm{~m}$, bosque muy húmedo premontano, epífitas en bosque primario, "in itinere per limitem Costa Rica et Panama inter montis Quijada del Diablo et montis Pando", 19 abril 2011, D. Bogarín 8651, D. Jiménez $\mathcal{E}$ A. Karremans (JBL-spirit). COSTA RICA. Puntarenas: Buenos Aires, Potrero Grande, Altamira, Parque Internacional La Amistad, Sector Altamira, ca. $1 \mathrm{~km}$ después de Cerro Frantzius, 9 $03^{\prime} 59.8^{\prime \prime} \mathrm{N} 82^{\circ} 58^{\prime} 54.2^{\prime \prime} \mathrm{W}, 2102 \mathrm{~m}$, bosque pluvial montano, 30 Agosto 2011, D. Bogarín 9107 $\mathcal{E}$ A. Karremans (JBL-spirit).

This species is distinguished by the non resupinate flowers, the lateral sepals ovate with the apical tails diverging, the lower lobe of petals lanceolate-subfalcate, up-curved and the pinkish column. Among the species of the group, it shares the non resupinate flowers with L. edwardsii, but the latter can be separated by the elliptic lateral sepals, the tails straight to curved inward, the rounded lower lobe of petals and the yellowish-white column.

Lepanthes edwardsii Ames, Bot. Mus. Leafl. 1(4): 4. 1933.

Type: HONDURAS. Comayagua: Pito Solo, Lake Yojoa, epiphyte in dense forest, $2000 \mathrm{ft}$ alt., 26 Aug 1932, J.B. Edwards 96 (holotype, AMES). Illustrations: Fig. 3B and 5. 

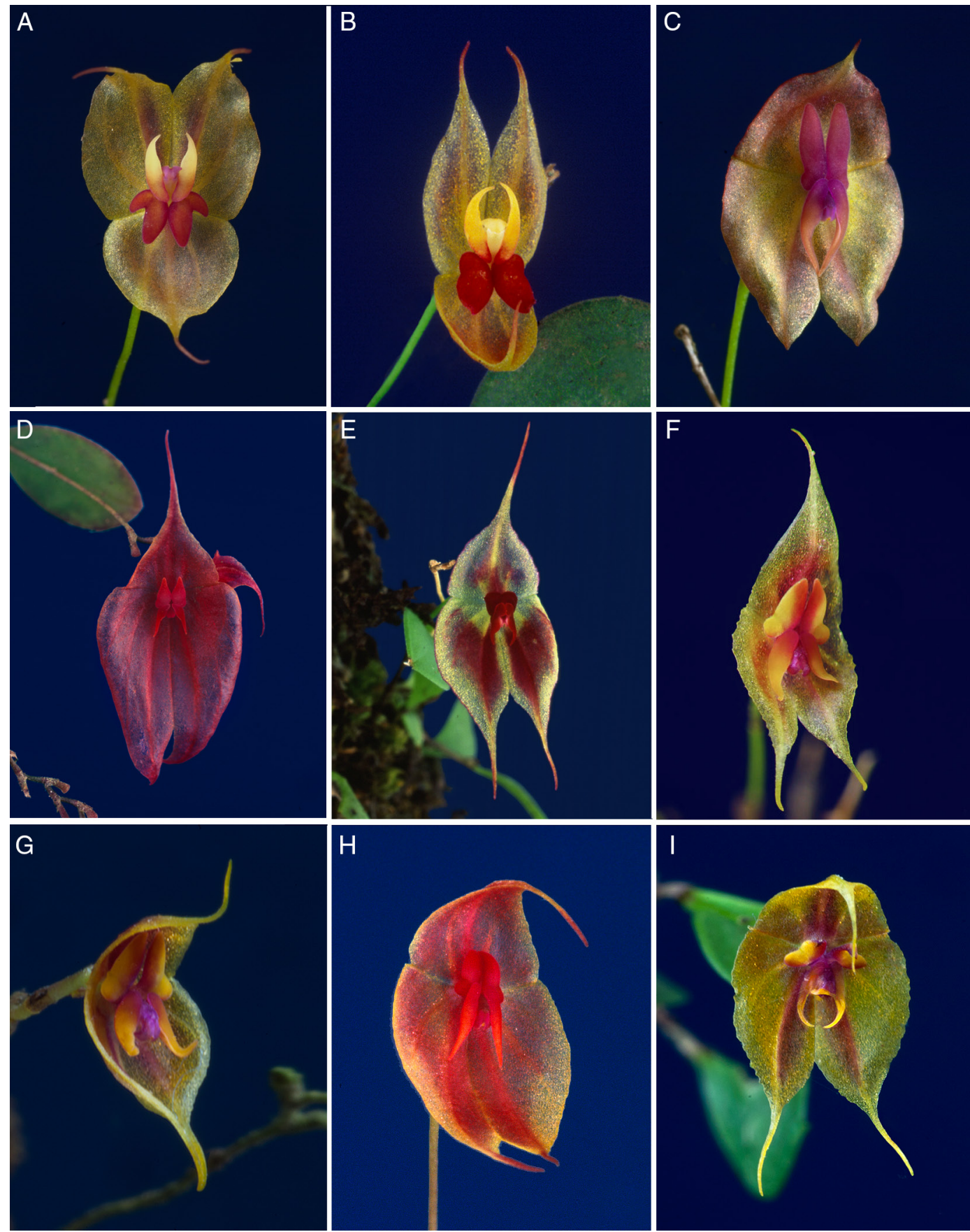

Fig. 3. Flowers of Lepanthes species of the L. guatemalensis group in Costa Rica: a, L. durikäensis; b, L. edwardsii; c, L. leporina; d, L. ruberrima; e, L. guanacastensis; f, L. sanctiorum; g, Lepanthes sanctiorum (autoganous form); h, L. schugii; i, L. tapantiensis.

Epiphytic, small, caespitose, erect herb, to $2.5 \mathrm{~cm}$ tall. Roots thick, glabrous, to $2 \mathrm{~mm}$ in diameter. Ramicauls slender, 0.8-1.4 cm long, enclosed by 2-3 glabrous, whitish sheaths. Leaf thinly coriaceous, elliptic to orbicular, rounded, conduplicate, deeply and narrowly retuse, with a distinct abaxial mucro, $8-10 \mathrm{~mm}$ long, $5.0-5.5 \mathrm{~mm}$ wide, shortly cuneate at the base into a petiole about $0.5 \mathrm{~mm}$ long. Inflorescence produced singly, larger than the leaf, a loose, distichous, successively flowered (to 7+ flowers) raceme to $2.8 \mathrm{~cm}$ long; filiform peduncle to $23 \mathrm{~mm}$ long, provided with 1-2 short tubular, obtuse bracts; rachis slightly fractiflex. Floral bracts broadly ovate, amplectent, subacute, ca. $1 \mathrm{~mm}$ long, $0.5 \mathrm{~mm}$ wide, sparsely muriculate; pedicel $1.3 \mathrm{~mm}$ long, glabrous; ovary $1.3 \mathrm{~mm}$ long, subtrigonous, smooth. Flowers non resupinate, large for the genus, with pale translucent yellow sepals, suffused with red along the midveins, the petals red, the lateral lobes of the lip yellow with the base suffused with red, the column yellow, the anther cap white. Dorsal sepal anguste ovate, contracted at apex into a subacute to acuminate tail ca. $3 \mathrm{~mm}$ long, $7.5 \mathrm{~mm}$ long including the tail, $2 \mathrm{~mm}$ wide, 3-veined, connate to the lateral sepals for $0.5 \mathrm{~mm}$. Lateral sepals anguste ovate-elliptic, connate for about half of their length into a suborbicular synsepal ca. $7.5 \mathrm{~mm}$ long (including the tails), $3 \mathrm{~mm}$ wide, apically contracted 

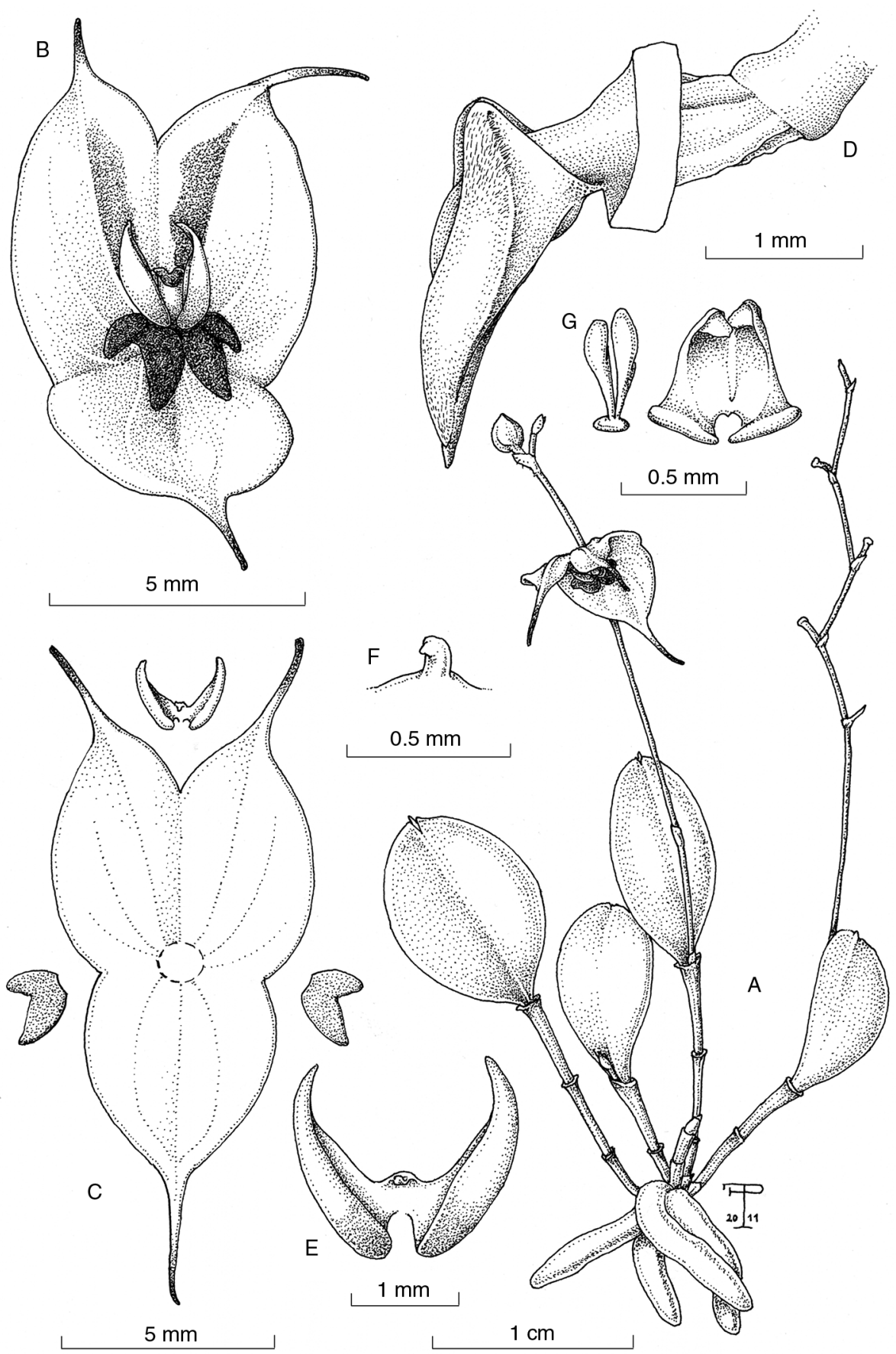

Fig. 4. Lepanthes durikäensis: a, habit; b, flower; c, dissected flower; d, ovary, column and lip, lateral view; e, lip, spread; f, appendix; g, pollinarium and anther cap. All drawn by F. Pupulin from Pupulin 8093 (JBL).

into acuminate tails wich are straight to curved inward ca. $2.5 \mathrm{~mm}$ long, connate to the dorsal sepal for $0.5 \mathrm{~mm}$. Petals transversely bilobed, $7 \mathrm{~mm}$ long, $1.9 \mathrm{~mm}$ wide, the upper lobes ovate to oblong, rounded, $1.3 \mathrm{~mm}$ long, $7 \mathrm{~mm}$ wide, the lower lobes smaller than the upper lobes, hemispheric, rounded to subacute, not curved upward, ca. $1.5 \mathrm{~mm}$ long, $1 \mathrm{~mm}$ wide. Lip bi-laminate, the blades narrowly digitatefalcate, acuminate, $2.2 \mathrm{~mm}$ long, $0.5 \mathrm{~mm}$ wide, adpressed to the column, the connectives trapezoidal, the body thin, rounded-protruding at apex, with a very thin, up-curved, digitate, glabrous appendix. Column short, truncate, to
$1 \mathrm{~mm}$ long, the anther apical, the stigma ventral. Anther cap cucullate, helmet-shaped, apically deeply bilobed. Pollinia 2, narrowly lanceolate, on a rounded, flat viscidium.

Eponymy: Dedicated to Oakes Ames' correspondent, James B. Edwards, who collected the type specimen during his field trip in Honduras in 1932-1933.

Distribution: Honduras to Costa Rica.

Habitat: Epiphytic in disturbed premontane wet forest on twigs of main trunks mostly on fences and exposed conditions. It was collected along the Cordillera Volcánica 


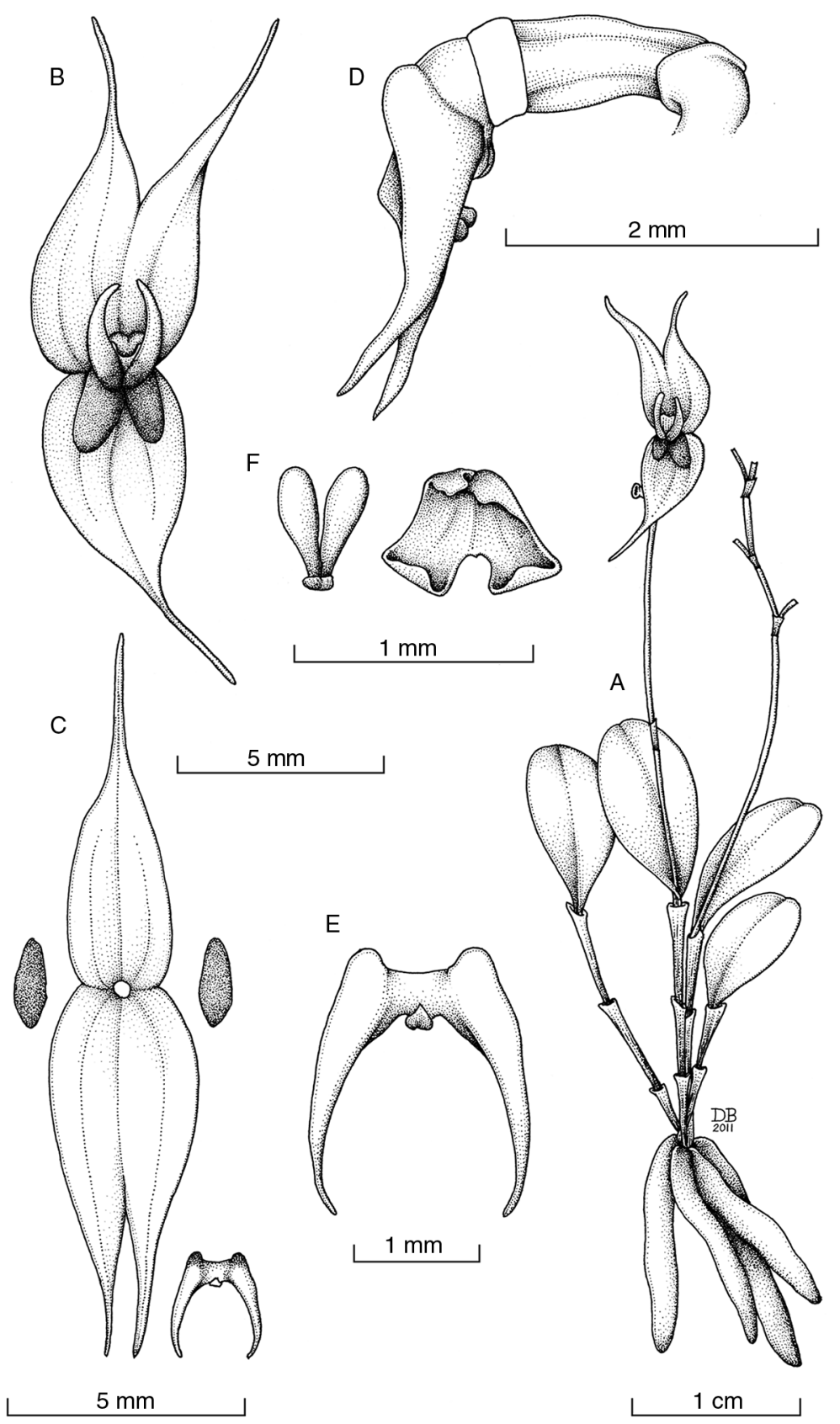

Fig. 5. Lepanthes edwardsii: a, habit; $\mathbf{b}$, flower; c, dissected flower; d, ovary, column and lip, lateral view; e, lip, adaxial view; f, pollinarium and anther cap. All drawn by D. Bogarín from Bogarín 573 (JBL).

Central and Cordillera de Talamanca from 1500 to $2000 \mathrm{~m}$ of elevation. Populations of typical Lepanthes edwardsii, from Honduras, are found at lowers elevation, at around 600 meters, in the area of Yojoa Lake.

Additional material examined: Heredia: San Rafael, camino al Monte de La Cruz, desviación al Residencial El Tirol, orillas del Río Segundo, cerca de Finca Villa Delia, 1840 m, $10^{\circ} 4^{\prime} 27^{\prime \prime} \mathrm{N} 84^{\circ} 5^{\prime} 8^{\prime \prime} \mathrm{W}$, bosque húmedo premontano, epífitas en bosque secundario, 28 diciembre 2003, D. Bogarin 573 (JBL-spirit). San José: Dota, El Jardín, Finca El Mirador, ca. 2000 m, 6 julio 2003, W. Schug 96 E Elena Naranjo (JBL-spirit). León Cortés, Frailes, San Martín. Alrededor de $3 \mathrm{Km}$ antes de el centro de acopio de APROCAM, al lado de la calle principal en árboles solitarios en potreros. $9^{\circ} 44^{\prime} \mathrm{N} 84^{\circ} 03^{\prime} \mathrm{W} .1500-1800$ m. Con Fruticultura UCR-SA, 8 junio 2007, A. Karremans 1782 (JBL-spirit). Dota, Santa María, Las Quebradillas, plaza en la cima, zona de vida LM-wf, 09 $41^{\prime} 25^{\prime \prime} \mathrm{N}, 83^{\circ} 57^{\prime} 16^{\prime \prime} \mathrm{W}, 2350 \mathrm{~m}, 29$ Set 2002, W. Schug s.n., D. Matamoros EJ.J. Zúniga Jara (USJ-spirit).

This taxon can be easily recognized by the non resupinate flowers, the anguste elliptic lateral sepals, the tails straight to curved inward, the rounded lower lobe of petals and the yellowish-white column. It is similar to $L$. durikäensis but the latter can be distinguished by the ovate lateral sepals with the apical tails diverging, the lower lobe of petals lanceolatesubfalcate, up-curved and the pinkish column. Costa Rican populations differ from typical L. edwardsii in the tailed sepals (vs. acute-acuminate), the petals with the upper lobe 
ovate-oblong, rounded (vs. lanceolate, acute), the blades of the lip are convergent (vs. divergent-subparallel), the petals red and the lip and column yellow (vs. petals, lip and column purple-wine). Further sampling from populations in the northern range of the species' distribution may perhaps reveal the existence of a complex of closely related taxa under our actual concept of L. edwardsii.

Lepanthes guanacastensis Ames \& C. Schweinf., Schedul. Orch. 10: 45. 1930.

Type: COSTA RICA. Guanacaste: Naranjos Agrios, 600-700 m, 29 Jan. 1926. "On tree; flowers red and green." P.C.
Standley \& J. Valerio 46440 (holotype, AMES). Illustrations: Fig. 3E and 6.

Epiphytic, small, caespitose, erect herb, about $2 \mathrm{~cm}$ tall. Roots thick, glabrous, flat, to about $2.5 \mathrm{~mm}$ in diameter. Ramicauls slender, to $9 \mathrm{~mm}$ long, enclosed by $2-3$ minutely scabrous, brown sheaths, terminating into a rather conspicuous, infundibuliform, hispid ostia. Leaf coriaceous, broadly cuneate-spatulate to obovate, rounded, minutely tridenticulate at apex, to $10 \mathrm{~mm}$ long, $3.5-5 \mathrm{~mm}$ wide, cuneate-narrowed at the base into an indistinct petiole about 1 $\mathrm{mm}$ long. Inflorescence 1 , rarely 2 per growth, produced singly behind the leaf at any new growth season, a loose,

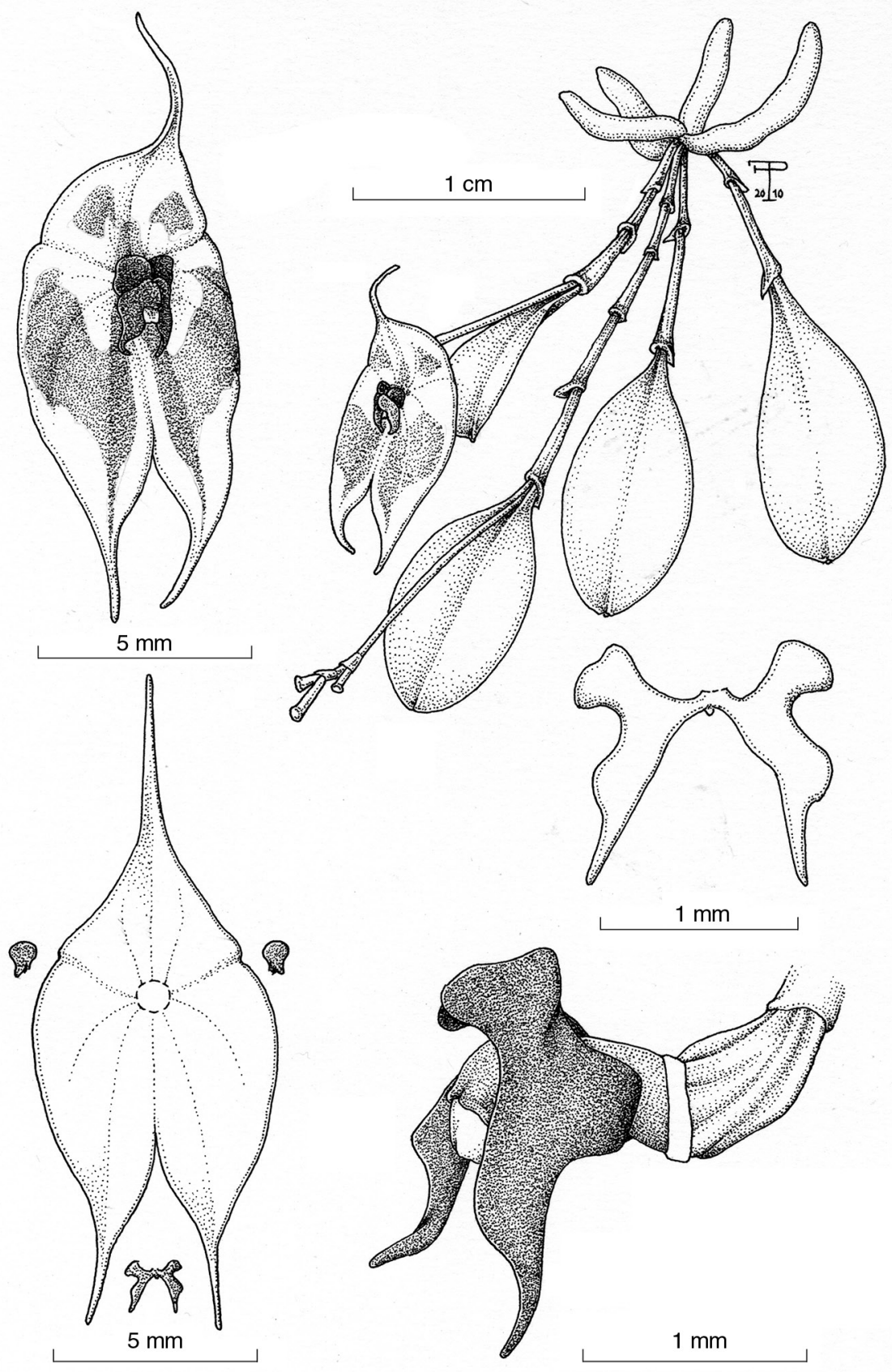

Fig. 6. Lepanthes guanacastensis: $\mathbf{a}$, habit; $\mathbf{b}$, flower; $\mathbf{c}$, dissected flower; $\mathbf{d}$, ovary, column and lip, lateral view; e, lip, spread. All drawn by the authors from Bogarín 2837 (JBL). 
distichous, successively 2- to 3-flowered raceme, $11-25 \mathrm{~mm}$ long; filiform peduncle, with a small tubular sheath in the middle; rachis fractiflex. Floral bracts infundibuliform, $1 \mathrm{~mm}$ long, glabrous; pedicel $2.3 \mathrm{~mm}$ long; ovary $0.8 \mathrm{~mm}$ long. Flowers large for the genus in Costa Rica, with greenish yellow sepals, blotched with red along and between the veins, petals red, the lateral lobes of the lip red, sometimes with orange apex, the column purple-red, the anther purple and white. Dorsal sepal triangular-ovate, contracted at apex into an acuminate tail about $7 \mathrm{~mm}$ long, $11.5 \mathrm{~mm}$ long including the tail, $5.5 \mathrm{~mm}$ wide, 3 -veined, dorsally carinate along the midvein, connate to the lateral sepals for $2.5 \mathrm{~mm}$. Lateral sepals connate for about half of their length into an ovate, 6-veined lamina, dorsally carinate along the midveins, the free apices extending into filiform tails about $4 \mathrm{~mm}$ long, $13.5 \mathrm{~mm}$ long including the tail, $7 \mathrm{~mm}$ wide, connate to the dorsal sepal for $2.5 \mathrm{~mm}$. Petals transversely bilobed, the upper lobes obovate-quadrate, broadly obtuse to truncate, $0.6 \mathrm{~mm}$ long, $0.5 \mathrm{~mm}$ wide, with a central, pyramidal callus projecting downward, the lower lobes very reduced, ear-like, $0.2 \mathrm{~mm}$ long, $0.2 \mathrm{~mm}$ wide. Lip 3-lobed, the lateral blades obliquely narrowly triangular, falcate, acuminate, provided with a with a transverse flabellate thickening at the base and a semi-elliptic abaxial projection at the middle, basally concave, $1.9 \mathrm{~mm}$ long, $1 \mathrm{~mm}$ wide, appressed to the column, the connectives narrowly rectangular, the appendix shortly triangular, glabrous. Column short, $0.8 \mathrm{~mm}$ long, the anther subapical, quadrate-ellipsoid, with 2 spreading triangular tips, the stigma ventral. Pollinia 2, oblong-pyriform.

Etymology: Named after the Province of Guanacaste, Costa Rica, where the type plant was collected.

Distribution. Endemic to Costa Rica.

Habitat: Epiphytic on twigs in exposed conditions in disturbed tropical wet forest, premontane belt transition on the Caribbean slopes of Cordillera de Guanacaste and Tilarán at around $600-700 \mathrm{~m}$ of elevation.

Additional material examined: COSTA RICA. Alajuela: Upala, Bijagua, Zapote, desvío a la izquierda después del puente sobre Río Zapote en sentido Bijagua-Pueblo Nuevo, ladera este del Volcán Miravalles, siguiendo la margen

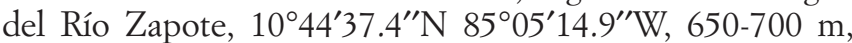
bosque muy húmedo tropical, transición a premontano, epífitas Citrus sp. en potreros, 30 abril 2006, D. Bogarín 2837, 2840 and 2841 (JBL-spirit).

This species can be identified by the pendent or suberect habit, with resupinate flowers, the caudate synsepal having the apices of the lateral sepals forming distinct tails, the upper lobes of the petals obovate-quadrate, broadly obtuse to truncate, with a central, pyramidal callus projecting downward, the lower lobes very reduced, ear-like, the upper lobe of the lip orbicular, the blades of the lip sigmoid, with a distinct basal lobe the lateral blades obliquely narrowly triangular, falcate, acuminate, provided with a transverse flabellate thickening at the base and the appendix very reduced, rounded. The above description of petals and lip is unique among its relatives.

Lepanthes leporina Pupulin \& Bogarín, sp. nov.

Type: COSTA RICA. Cartago: Paraíso, Orosi, Tapantí, sendero que va desde Kiri Lodge a la catarata, $9^{\circ} 46^{\prime} 30.66^{\prime \prime} \mathrm{N}$ $83^{\circ} 47^{\prime} 35.40^{\prime \prime} \mathrm{W}, 1336 \mathrm{~m}$, sobre árbol de ciprés (Cupressus lussitanica) en ramitas terminales, bosque pluvial premontano,, 8 July 2011, Daniel Jiménez s.n. (holotype, JBL-spirit). Illustrations: Fig. 3C and 7.

Habitu Lepanthem ruberrimae Pupulin affinibus similis praecipue differt sepalis flavis leviter suffusis roseis, petalis violaceis, labello aurantiaco, sepalis lateralibus non caudatis subequalibus sepalo dorsali, petalis valde convexis, lobo superiore petalorum elliptico-lanceolato, lobis labellorum in apice conniventibus.

Epiphytic, small, caespitose, erect herb, to $2 \mathrm{~cm}$ tall. Roots thick, glabrous, 1.8-2.4 mm in diameter. Ramicauls slender, $0.8-1.2 \mathrm{~cm}$ long, enclosed by 3-4 glabrous, whitish sheaths. Leaf thinly coriaceous, broadly elliptic-suborbicular, rounded, minutely emarginated, with a small abaxial mucro, $9-11 \mathrm{~mm}$ long, $7-8 \mathrm{~mm}$ wide, cuneate at the base into a petiole about $0.5 \mathrm{~mm}$ long. Inflorescence several per growth, produced singly behind the leaf at any new growth season, a loose, distichous, successively few-flowered (to 5 flowers) raceme to $20 \mathrm{~mm}$ long; filiform peduncle to $15 \mathrm{~mm}$ long, provided with a short tubular, obtuse bract. Floral bracts transversely broadly ovate, amplectent, obtuse, $0.5 \mathrm{~mm}$ long, $0.8 \mathrm{~mm}$ wide, sparsely and microscopically muriculate; pedicel $1.5 \mathrm{~mm}$ long, sparsely muriculate; ovary $1.2 \mathrm{~mm}$ long, subtrigonous. Flowers large for the genus, with yellow sepals, faintly suffused with red along the midvein and the upper sepal margins, the petals violet-red, the lateral lobes of the lip orange with the base violet, the column and the anther cap violet. Dorsal sepal broadly triangularovate, contracted at apex into an acuminate tail $1 \mathrm{~mm}$ long, $7.5 \mathrm{~mm}$ long including the tail, $5.5 \mathrm{~mm}$ wide, 5 -veined, connate to the lateral sepals for $2.5 \mathrm{~mm}$. Lateral sepals connate for two thirds of their length into a broadly ovate, bifid lamina with subacute apices, $7 \mathrm{~mm}$ long, $7.5 \mathrm{~mm}$ wide, connate to the dorsal sepal for $2.5 \mathrm{~mm}$. Petals transversely bilobed, minutely pubescent, $0.8 \mathrm{~mm}$ long, $2.5 \mathrm{~mm}$ wide, the upper lobes elliptic-sublanceolate, rounded, $0.8 \mathrm{~mm}$ long, $2.2 \mathrm{~mm}$ wide, the lower lobes obsolescent, semicircular, ca. $0.5 \mathrm{~mm}$ long, $0.7 \mathrm{~mm}$ wide. Lip bi-laminate, the blades narrowly digitate-falcate, acuminate, $3 \mathrm{~mm}$ long, $0.5 \mathrm{~mm}$ wide, adpressed to the column, the connectives trapezoidal, the body thin, rounded, with a very thin, incurved, aculeate, glabrous appendix. Column short, truncate, $1.4 \mathrm{~mm}$ long, the anther apical, the stigma ventral. Anther cap cucullate, helmet-shaped, apically deeply bilobed. Pollinia 2, elliptic, on two separate, hyaline, rectangular caudicles.

Etymology: From the Latin leporinus, "of the hare", in allusion to the shape of the petals reminding the long ears of leporids.

Distribution: Known only from the type locality in Costa Rica.

Habitat: Epiphytic on twigs of Cupressus lusitanica in disturbed premontane wet forest on the Caribbean slopes of Talamanca range in the region of Tapantí, at about 1300 meters of elevation.

The new taxon can be recognized by the resupinate flowers with yellow sepals, faintly suffused with red, the petals violet, the lip orange, the bifid synsepal with the apices of the lateral sepals not forming tails, the lateral sepals subequal to the dorsal sepal, the petals markedly convex with the upper lobe elliptic-lanceolate and the blades of the lip with connivent apices. It is similar to L. ruberrima but 


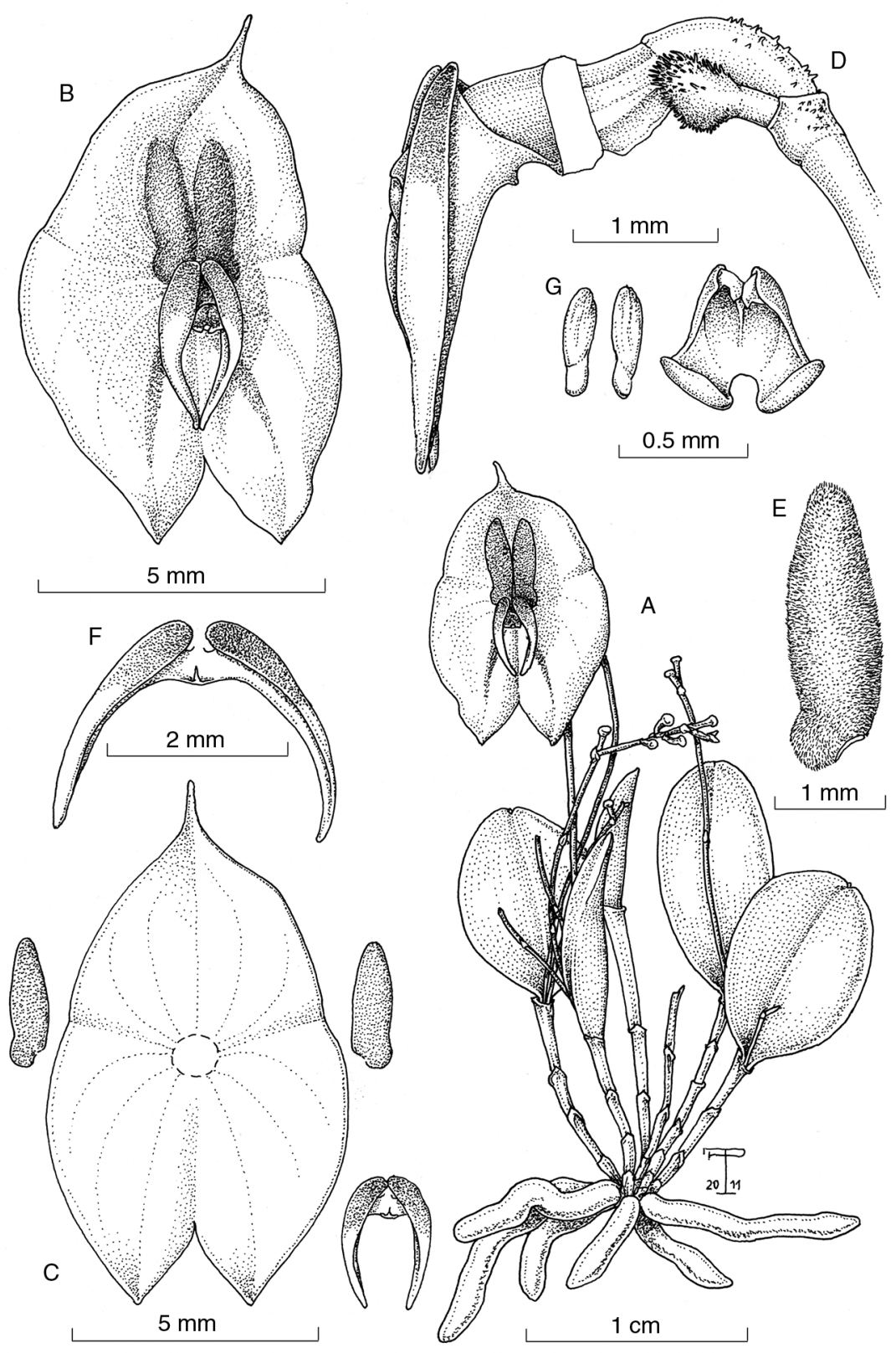

Fig. 7. Lepanthes leporina: a, habit; b, flower; c, dissected flower; $\mathbf{d}$, pedicel, ovary, column and lip, lateral view; e, lip, spread; $\mathbf{f}$, petal; g, pollinia and anther cap. All drawn by F. Pupulin from Jiménez s.n. (JBL).

the later can be recognized by the concolorous purple-red flowers, the lateral sepals much longer than the dorsal sepal and the petals flat with the upper lobe triangular and the blades of the lip without connivent apices. Lepanthes schugii is another species similar to L. leporina, however it could be easily separated by the caudate synsepal having the apices of the lateral sepals forming distinct tails and the blades of the lip without connivent apices.

Lepanthes ruberrima Pupulin, Orch. Digest 76(1): 23.2012. Basionym: Lepanthes johnsonii subsp. costaricensis Pupulin, Harvard Pap. Bot. 6(1): 291. 2001.

Type: COSTA RICA: Cartago: Orosi, road to the Parque Nacional Tapantí, about $1 \mathrm{~km}$ before the entrance of the park, $1160 \mathrm{~m}$, epiphytic on a short tree along the roadside, 6 Feb 2000, F. Pupulin 1979 [holotype, USJ, apparently lost; neotype, designated by Pupulin \& Bogarín (2012), COSTA RICA. Cartago: Orosi, Tapantí, Purisil, road to Tapantí National Park, between restaurant Kirí and the entrance of the Park, about $1 \mathrm{~km}$ before the entrance, $9^{\circ} 45^{\prime} 50.4^{\prime \prime} \mathrm{N}$ $83^{\circ} 47^{\prime} 24.4^{\prime \prime} \mathrm{W}, 1245 \mathrm{~m}$, epiphytic on short fence trees along the roadside, premontane wet forest, 20 August 2007, F. Pupulin 6859, M. Pupulin E C. Pupulin (CR)]. Illustrations: Fig. 3D and 8.

Epiphytic, small, caespitose, erect to pendent herb, to $2.5 \mathrm{~cm}$ tall. Roots thick, glabrous, $1.5-1.8 \mathrm{~mm}$ in diameter. Ramicauls slender, 0.6-1.2 cm long, enclosed by 2-3 glabrous, brown sheaths. Leaf thinly coriaceous, elliptic, obtuse, minutely tridenticulate at apex, $7-8 \times 4 \mathrm{~mm}$, 

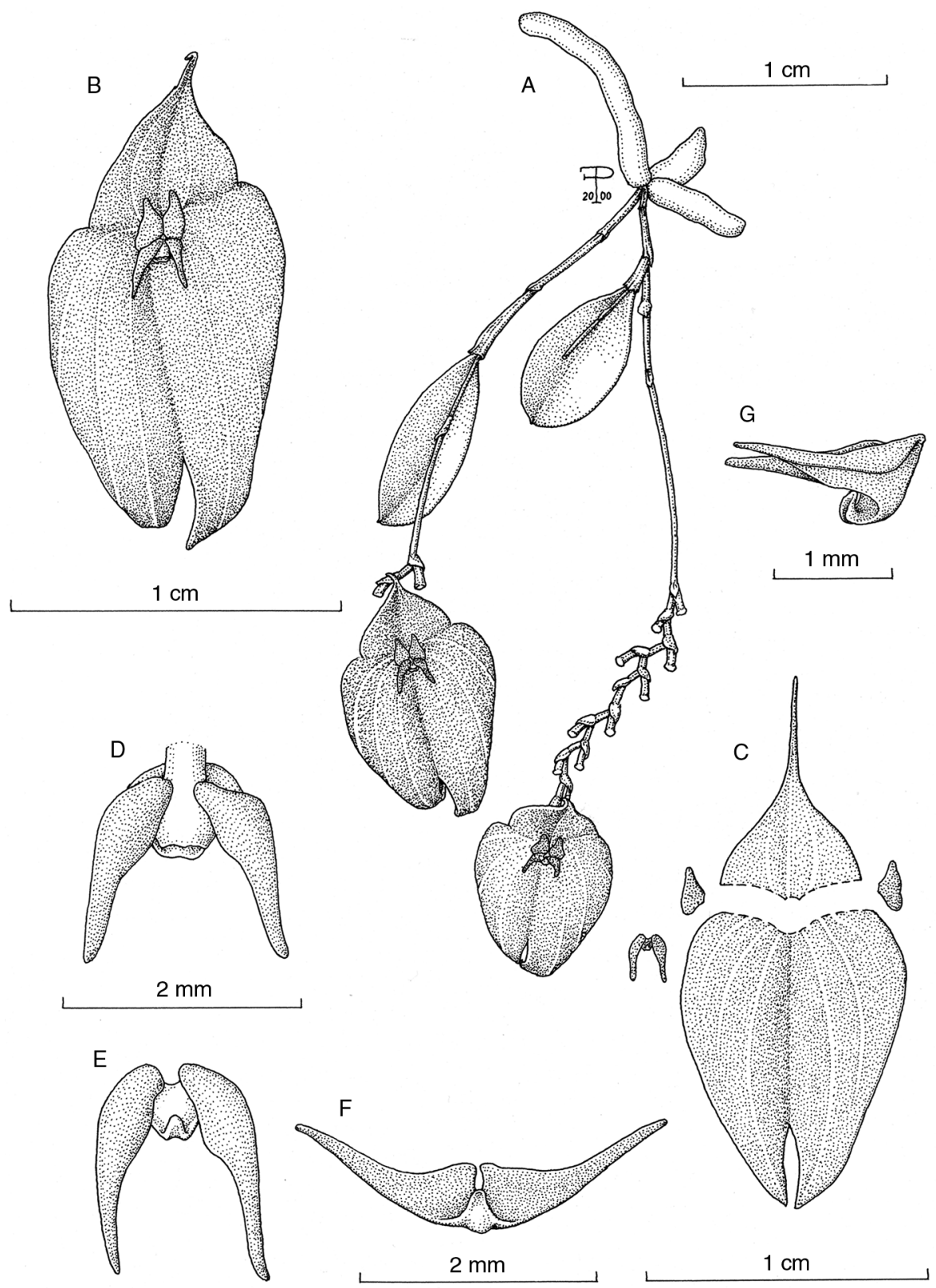

Fig. 8. Lepanthes ruberrima: a, habit; b, flower; c, dissected flower; d, column and lip, from above; e, lip, adaxial view, in natural position; $\mathbf{f}$, lip, adaxial view, spread; g, lip, lateral view. All drawn by F. Pupulin from Pupulin 1979 (JBL).

cuneate at the base into a petiole about $1 \mathrm{~mm}$ long. Inflorescence 1-2 per growth, produced singly behind the leaf at any new growth season, a loose, distichous, successively few-flowered (to 11 flowers) raceme to $32 \mathrm{~mm}$ long; filiform peduncle to $15 \mathrm{~mm}$ long, covered at the base by a tubular sheath; rachis fractiflex. Floral bracts widely ovate, $0.8 \times 0.7 \mathrm{~mm}$, glabrous; pedicel $1.8 \mathrm{~mm}$ long; ovary $1 \mathrm{~mm}$ long. Flowers large for the genus, with purple sepals, petals red-purple, the lateral lobes of the lip red-purple with yellow apex, and red-purple column. Dorsal sepal very broadly triangular-ovate, contracted at apex into an acuminate tail $4 \mathrm{~mm}$ long, $8.5 \times 5.5 \mathrm{~mm}$ including the tail, 3 -veined, connate to the lateral sepals for $2.5 \mathrm{~mm}$. Lateral sepals connate for three quarters of their length into a broadly ovate, bifid lamina with acute apices, $11 \times 8.5 \mathrm{~mm}$, connate to the dorsal sepal for $2.5 \mathrm{~mm}$. Petals transversely bilobed, $0.8 \times 1.9 \mathrm{~mm}$, the upper lobes obliquely triangular, $0.6 \times 1.2 \mathrm{~mm}$ wide, the lower lobes smaller, semicircular, $0.6 \times 0.5 \mathrm{~mm}$ wide. Lip 3-lobed, $0.6 \times 3.2 \mathrm{~mm}$ across the lateral lobes when spread, the lateral blades narrowly triangular-falcate, acute, $1.7 \times 0.5 \mathrm{~mm}$, appressed to the column, the connectives triangular, the appendix oblong, incurved, cleft abaxially from revolute sides, glabrous. Column short, winged, $0.8 \mathrm{~mm}$ long, the anther subapical, the stigma ventral. Pollinia 2, ovoid.

Etymology: From the Latin ruberrimus, "very red", in allusion to the color of the flower.

Distribution: Endemic to Costa Rica.

Habitat: Epiphytic in premontane wet forest in the region of Tapantí, at about 1200 meters of elevation, where it has been 
recorded exclusively from the quite exposed trunks of short trees forming a fence along the road to Tapantí Naional Park. Additional material examined: Costa Rica. Cartago: Orosi, road to the Parque Nacional Tapantí, about $1 \mathrm{~km}$ before the entrance of the Park, $1170 \mathrm{~m}$, epiphytic on short trees along the roadside, bordering a pasture, 7 May 2000, F. Pupulin 2409 E Curso de Orquideología (USJ!).

Originally described as a subspecies of $L$. jobnsonii Ames (Pupulin, 2001), a species ranging from Mexico to Guatemala, L. ruberrima shows consistent morphological differences with its northern relative (Pupulin \& Bogarín 2012). Lepanthes ruberrima has glabrous caulinar sheets (vs. hispidulous in L. jobnsonii), distinctly shorter leaves $(<8 \mathrm{~mm}$ vs. $>10 \mathrm{~mm}$ ), lateral sepals forming a broadly ovate, bifid lamina with acute apices (vs. with the lobes distinctly caudate), and the upper lobe of the petals triangularrounded (vs. narrowly triangular, acute). Furthermore, the flowers of L. ruberrima are completely red-purple, while in L. jobnsonii they vary from pink to yellow, with the tails of the sepals suffused with rose-purple, the petals usually rose-purple, and the laminae of the lip yellow, flushed with red only at the base. It is also similar to L. leporina but the later can be separated by the elliptic-lanceolate upper lobe of petals, the blades of the lip with connivent apices and and the overall color of the flower (see the above discussion of L. leporina).

\section{Lepanthes sanctiorum Bogarín \& Pupulin, sp. nov}

Type: COSTA RICA. San José: Dota, San Lorenzo, parte alta de San Lorenzo de Dota, potreros en el camino hacia el

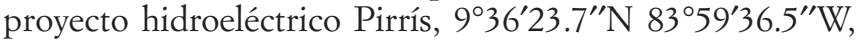
1800 m, legit Daniel Jiménez, floreció en cultivo en el Jardín Botánico Lankester, 1 marzo 2011, D. Bogarín 8415 (holotype, JBL-spirit). Illustrations: Fig. 3F, 3G, 9, 10.

Habitu Lepanthem tapantiense Pupulin \& Bogarín affinis sed stirpe pedunculoque breviore, latitudine petalorum lobulos labelli aequantibus, lobulis labelli in apice divergeventibus etiam floribus synsepalo naviculare sepalibus lateralibus usque ad apicem conjunctis, polliniis anguste oblongis caudiculis perbrevis.

Epiphytic, cespitose, erect herb, to $1.1 \mathrm{~cm}$ tall. Roots coarse, glabrous, to $0.6 \mathrm{~mm}$ in diameter. Ramicauls slender, 1.2-4.8 $\mathrm{mm}$ long, enclosed by $2-3$ concealing, glabrous, brownish, lepanthiform sheaths, slightly dilated at the acute apices. Leaf elliptic to obovate-elliptic, rounded, minutely retuse, with a short abaxial apicule, thin-coriaceous, cuneate at the base into a short conduplicate petiole, 3.5-7.7 $\times 1.8-3.7 \mathrm{~mm}$ including the petiole. Inflorescence a distichous, loose, successively 1 - to 2 -flowered raceme to $7 \mathrm{~mm}$ long, produced over the leaf by a slender, terete peduncle, $3.5 \mathrm{~mm}$ long, provided with 1 brownish, adpressed, lanceolate, acute bracts to $0.7 \mathrm{~mm}$ long. Floral bracts subequal to the bracts of the inflorescence, $0.7 \mathrm{~mm}$ long, shorter than the ovary; pedicel terete, to $1 \mathrm{~mm}$ long, persistent; ovary subclavate, winged, ca. $1 \mathrm{~mm}$ long, the margins of the crests cartilagineous, irregularly crenulate. Flowers large for the plant, the sepals yellow, basally flushed with red between veins, the petals proximally red, distally yellow, the lip yellow, suffused with red at the base of the blades, the column pinkish-red, the anther lilac-violet.
Sepals connate, forming a spreading 3-lobed calyx with caudate lobes. Dorsal sepal ovate-triangular, 3-veined, acuminate or ending into a filiform tail, connate at the base to the lateral sepals for $1.3 \mathrm{~mm}$, irregularly and shallowly crenulate along the basal margins, $5.1 \times 2.7 \mathrm{~mm}$ including the tail. Lateral sepals ovate, abruptly constricted at apex into a filiform tail $1.4 \mathrm{~mm}$ long, connate to each other for ca. $1.2 \mathrm{~mm}$, the somewhat margins crenulate, $5.1 \times 3.5 \mathrm{~mm}$. Petals transversely bilobed, $0.8 \times 1.5 \mathrm{~mm}$, glabrous, with the upper lobe oblong, rounded, $0.8 \times 1.0 \mathrm{~mm}$; the lower lobe smaller than the upper lobe, suborbicular, $0.8 \times 0.4 \mathrm{~mm}$, the upper lobe obliquely triangular-ovate, minutely rounded. Lip 3-lobed, bilaminate, 1 long $\mathrm{mm}$ across the lateral lobes, the body $2 \mathrm{~mm}$ long, when spread, the lateral blades narrowly triangular-falcate, subparallel, without convergent or connivent apices, slightly concave adaxially, not joining at the acute, apex, basally adpressed to the column, the lobules $1.6 \times 0.3 \mathrm{~mm}$, the connectives cylindric, the appendix filiform, glabrous. Column terete, minutely papillose, ca. $1 \mathrm{~mm}$ long, the anther subdorsal, the stigma ventral. Anther cap ovate, 2 -celled, the base deeply emarginated, the apex provided with 2 flap-like, subquadrate, diverging lobes. Pollinia 2, narrowly linear-oblong, strongly complanate, with a rounded viscidium.

Etymology: Named after the type locality, the region known as Los Santos (the Saints) of Dota, León Cortés and Tarrazú of San José, in central Pacific Talamanca range.

Distribution: Known only from Costa Rica.

Habitat: epiphytic on Cupressus lusitanica trees in fences on exposed condition at around $1800 \mathrm{~m}$ of elevation in premontane rain forest on the Pacific watershed of Cordillera de Talamanca in southern Costa Rica.

\section{Additional material examined (paratypes)}

COSTA RICA. Cartago: La Unión, San Rafael, Cerros de La Carpintera, Campamento Escuela Iztarú, 953'08.2"N $83^{\circ} 58^{\prime} 15.6^{\prime \prime} \mathrm{W}, 1778 \mathrm{~m}$, bosque húmedo premontano, epífitas en potreros arbolados, 30 octubre 2008, D. Bogarín 5456, R.L. Dressler, R. Gómez, F. Pupulin, \& R. Trejos (JBL-spirit).

This new species is distinguished by the small size of the plants, less than $1.1 \mathrm{~cm}$ long, the short peduncle less than $10 \mathrm{~mm}$ long, the petals as wide as the lip length and the blades of the lip distinctly diverging at apex. It could be similar to $L$. tapantiensis and $L$. schugii but the later have longer plants and peduncles more than $1.3 \mathrm{~cm}$ long, the petals are distinctly narrower than the lip length and the blades of the lip are subparallel to converging at apex. Some plants collected at La Carpintera (Bogarín \& al. 5456) present autogamous flowers, navicular synsepals, the sepals joined until the apex and the pollinia narrowly oblong, with short caudicles (ratio caudicle/pollinium 1:10) Fig. 3G, 10. Populations from the type locality have flat synsepals, free apices of the sepals and the pollinia elliptic-subovate, with long caudicles (ratio caudicle/pollinium 1:2). We considered the specimens from La Carpintera the same as the species we are describing as L. sanctiorum. In spite of the former differences, the overall shape and color of flowers are very similar and the differences could be explained by the autogamous condition of the flowers. 


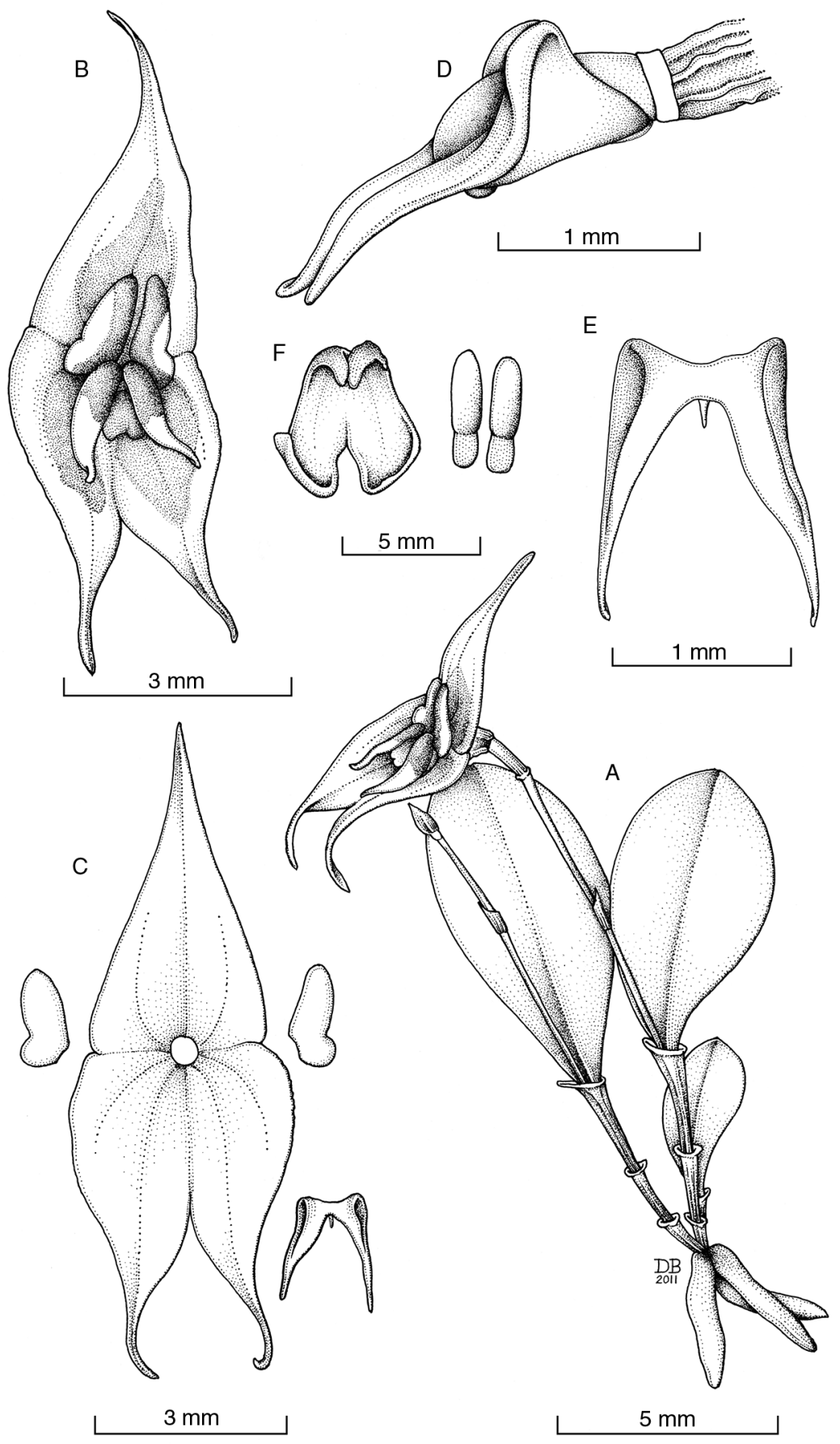

Fig. 9. Lepanthes sanctiorum: a, habit; b, flower; c, dissected flower; d, ovary, column and lip, lateral view; e, lip, adaxial view; f, anther cap and pollinia. All drawn by D. Bogarín from Bogarín 8415 (JBL).

Lepanthes schugii Pupulin, Orchidee (Hamburg) 54: 78. 2003.

Type: COSTA RICA. San José: Dota, Santa María, Las Quebradillas, $09^{\circ} 41^{\prime} 32^{\prime \prime} \mathrm{N}, 83^{\circ} 58^{\prime} 30^{\prime \prime} \mathrm{W}, 2100 \mathrm{~m}, 22$ Apr 2001, W. Schug s.n. (holotype, USJ). Illustrations: Fig. $3 \mathrm{H}$ and 11.

Epiphytic, caespitose, erect herb, to $2 \mathrm{~cm}$ tall. Roots slender, glabrous, ca $1 \mathrm{~mm}$ in diameter. Ramicauls slender, $0.8-1 \mathrm{~cm}$ long, enclosed by 3 blackish, microscopically pubescent, lepanthiform sheaths with dilated ostia. Leaf coriaceous, elliptic, obtuse, 8-10 mm long, 5-6 mm wide, cuneate at the base into a petiole about $0.5 \mathrm{~mm}$ long. Inflorescence a loose, successively few-flowered raceme to $20 \mathrm{~mm}$ long, produced behind the leaf by a filiform peduncle to $18 \mathrm{~mm}$ long. Floral bracts infundibuliform, $1.5 \mathrm{~mm}$ long, glabrous; pedicel $2.5 \mathrm{~mm}$ long; ovary $0.5 \mathrm{~mm}$ long. Flowers with yellow sepals, suffused with purple toward the center, the petals red, the lip rose-purple, the column purple. Dorsal sepal triangularovate, $4 \mathrm{~mm}$ long, $3 \mathrm{~mm}$ wide, apically contracted into a tail ca $2.5 \mathrm{~mm}$ long, connate to the lateral sepals for $1.2 \mathrm{~mm}$. Lateral sepals ovate-lanceolate, acute, $5 \mathrm{~mm}$ long, $2.5 \mathrm{~mm}$ wide, contracted at apex into a tail $1 \mathrm{~mm}$ long, connate $2.5 \mathrm{~mm}$. Petals 


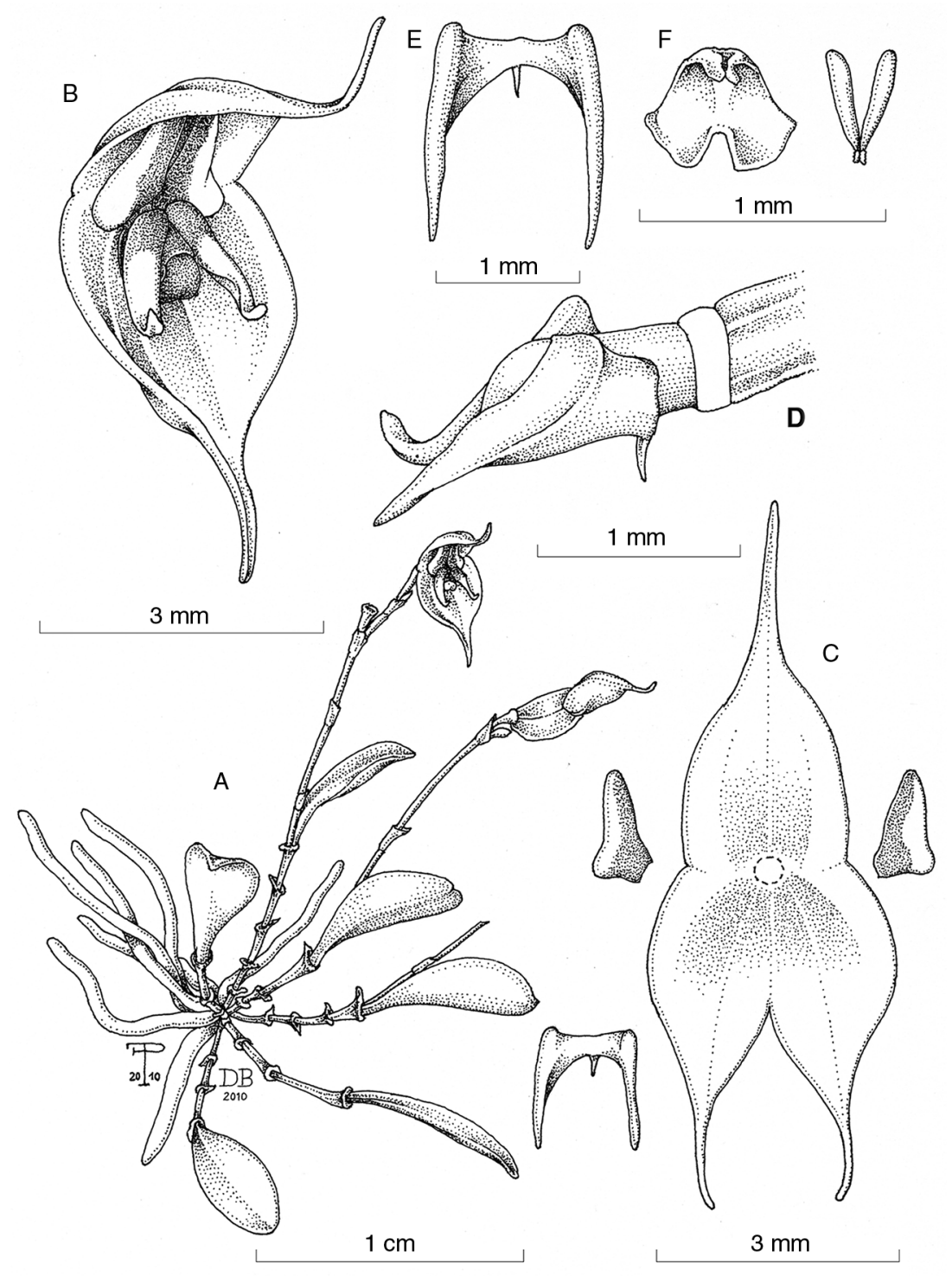

Fig. 10. Lepanthes sanctiorum (autoganous form): a, habit; b, flower; c, dissected flower; d, ovary, column and lip, lateral view; e, lip, adaxial view; f, anther cap and pollinarium. Drawn by the authors Bogarín 5456 (JBL).

glabrous, transversely bilobed, $0.5 \mathrm{~mm}$ long, $1.5 \mathrm{~mm}$ wide; the upper lobes narrowly ovate, subacute, $0.5 \mathrm{~mm}$ long, $1 \mathrm{~mm}$ wide, the lower vestigial, suborbicular, obtuse, $0.5 \mathrm{~mm}$ long, $0,5 \mathrm{~mm}$ wide. Lip bilaminate, the blades narrowly lanceolate, subfalcate, acute, glabrous, $2 \mathrm{~mm}$ long, the connectives narrowly cuneate, the body shortly connate to the half of column, the appendix cylindric, minutely papillose. Column terete, $1 \mathrm{~mm}$ long, the anther dorsal, the stigma apical. Anther cap ovate, basally deeply emarginate. Pollinia 2 , narrowly oblong.

Eponymy: Dedicated to Walter Schug, a German engineer in computer science who first collected the species.

Distribution: Endemic to Costa Rica.

Habitat: Epiphytic in lower montane wet forest at about 2000-2350 m of elevation in the region of Dota, on the Pacific watershed of Cordillera de Talamanca.

Additional material examined: COSTA RICA. San José: Dota, Santa María, Las Quebradillas, Finca del Sr. Arrieta, zona de vida LMwf, $09^{\circ} 41^{\prime} 24^{\prime \prime} \mathrm{N}, 83^{\circ} 57^{\prime} 53^{\prime \prime} \mathrm{W}, 2150 \mathrm{~m}$,
29 Set 2002, W. Schug 62, Juan José Zúñiga Jara, Daniel Matamoros E Eduardo Arrieta (JBL-spirit).

This species is distinguished by the peduncle $>13 \mathrm{~mm}$ long, the resupinate flowers, the petals distinctly narrower than the lip length, the blades of the lip subparallel, the basal margins of the synsepal plain, the lower lobe of petals much smaller, rounded, the upper lobe lanceolate, without a mucro and blades of the lip straight, subparallel to slightly diverging but without connivent apices. It is similar to L. tapantiensis but the latter can be distinguished by the basal margins of synsepal wavy-subcrenulate, the petals with the upper and lower lobes subequal, with a small mucro in between and the baldes of the lip incurved-uncinate.

Lepanthes tapantiensis Pupulin \& Bogarín, Orch. Digest 76(1): 25. 2012.

Type: COSTA RICA. Cartago: Paraíso, Orosi, Tapantí, Tapantí National Park, near the Mirador Point, Alto Patillos, 

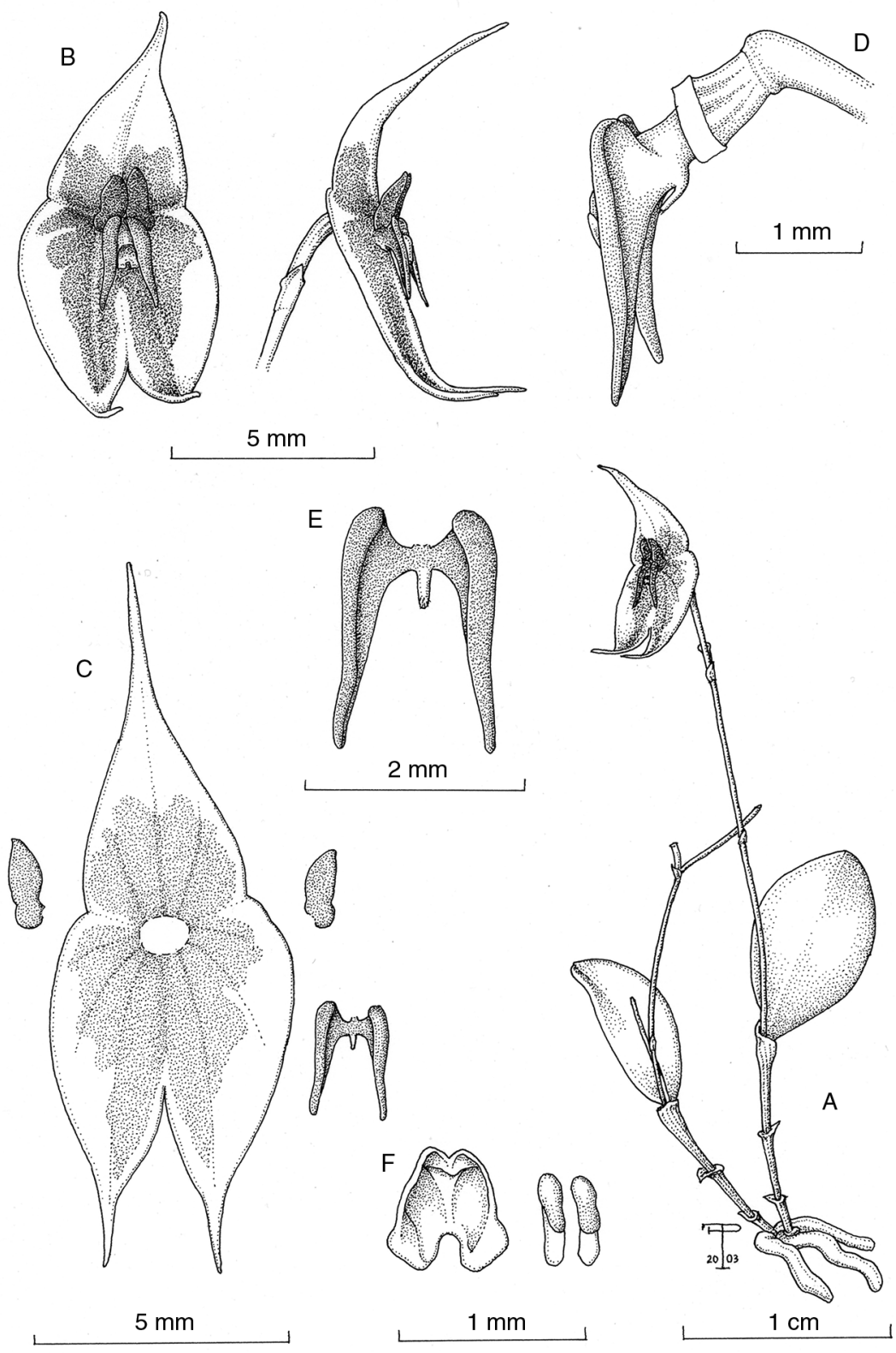

Fig. 11. Lepanthes schugii: a, habit; b, Flower, frontal and lateral views; $\mathbf{c}$, dissected flower; d, pedicel, ovary, column and lip, lateral view; e, lip, adaxial view; f, anther cap and pollinarium. All drawn by F. Pupulin from Schug s.n (USJ).

$9^{\circ} 44^{\prime} 04.22^{\prime \prime} \mathrm{N} 83^{\circ} 46^{\prime} 41.17^{\prime \prime} \mathrm{W}, 1470 \mathrm{~m}$, epiphytic on small trees along the main road, premontane rain forest, mature vegetation, 18 November 2010, F. Pupulin 8010, D. Bogarín, A. Karremans, R. Gómez, B. Klein E G. Meza (holotype, JBL). Fig. 3I and 12.

Epiphytic, cespitose, erect herb, to $2 \mathrm{~cm}$ tall. Roots coarse, glabrous, to $1.5 \mathrm{~mm}$ in diameter. Ramicauls slender, 7-12 mm long, enclosed by 2-3 concealing, glabrous, whitish, lepanthiform sheaths, slightly dilated at the acute apices. Leaf elliptic to obovate-elliptic, rounded, minutely retuse, with a short abaxial apicule, thin-coriaceous, cuneate at the base into a short conduplicate petiole, $6.5-11.0 \times 3.0-6.5 \mathrm{~mm}$ including the petiole. Inflorescence a distichous, loose, successively 1- to 2 -flowered raceme to $15 \mathrm{~mm}$ long, produced over the leaf by a slender, terete peduncle, $1.3 \mathrm{~cm}$ long, provided with
2-3 brownish, adpressed, lanceolate, acute bracts to $1.3 \mathrm{~mm}$ long. Floral bracts glumaceous, glabrous, broadly lanceolate, $0.7 \times 0.5 \mathrm{~mm}$; pedicel terete, to $1.5 \mathrm{~mm}$ long, persistent; ovary subclavate, winged, ca. $1 \mathrm{~mm}$ long, the margins of the crests cartilagineous, irregularly crenulate. Flowers large for the plant, spreading, resupinate, the sepals yellow, the dorsal one suffused with purple-red along the midvein, the lateral ones suffused with purple-red along the labellar side of the midvein, the petals yellow, blotched with red on the proximal margins, the apex of the upper lobe violet, the lip yellow, the blades red at the base, the column violet, the anther yellow. Sepals connate, forming a spreading 3-lobed calyx with caudate lobes. Dorsal sepal triangular, 3 -veined, ending into a filiform tail $2.5 \mathrm{~mm}$ long, connate at the base to the lateral sepals for $1.7 \mathrm{~mm}$, irregularly and shallowly crenulate along the basal margins, $7 \times 4 \mathrm{~mm}$ including the tail. Lateral sepals ovate, 


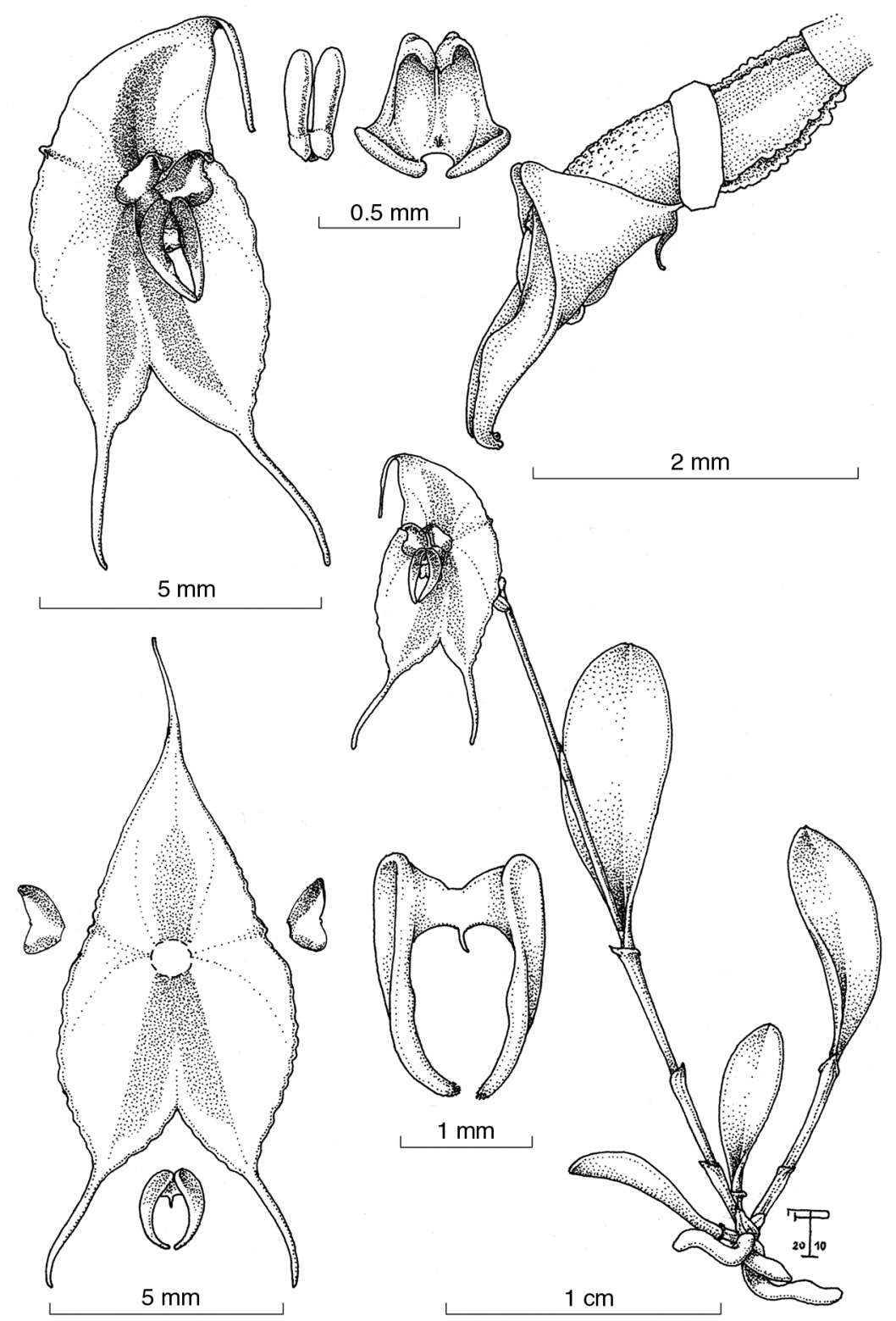

Fig. 12. Lepanthes tapantiensis: a, habit; b, flower, frontal and lateral views; c, dissected flower; d, pedicel, ovary, column and lip, lateral view; e, lip, spread; f, pollinarium and anther cap. All drawn by F. Pupulin from Pupulin 8010 (JBL).

abruptly constricted at apex into a filiform tail $3 \mathrm{~mm}$ long, connate to each other for ca. $3 \mathrm{~mm}$, the margins crenulate, $8.0 \times 2.7 \mathrm{~mm}$. Petals transversely bilobed, sub-obreniform, the lobes separated by a rounded apicule, glabrous, $0.7 \times 1.5 \mathrm{~mm}$, the upper lobe obliquely triangular-ovate, minutely rounded, $1.2 \times 0.8 \mathrm{~mm}$, the lower lobe smaller, elliptic, rounded, $1.0 \times 0.5$ $\mathrm{mm}$. Lip 3-lobed, bilaminate, $1.7 \times 1.4 \mathrm{~mm}$ across the lateral lobes when spread, the lateral blades narrowly triangular-falcate, slightly concave adaxially, joining at the acute, papillose apices, basally adpressed to the column, $1.7 \times 0.4 \mathrm{~mm}$, the connectives obcuneate, the appendix filiform, glabrous, white. Column terete, minutely papillose, ca. $1 \mathrm{~mm}$ long, the anther subdorsal, the stigma ventral. Anther cap ovate, 2-celled, the base deeply emarginated, the apex provided with 2 flap-like, subquadrate, diverging lobes. Pollinia 2, narrowly linearoblong, strongly complanate, with a rounded viscidium.
Etymology: Named from the region of Tapantí and the homonymous National Park.

Distribution: Known only from the type locality in Costa Rica.

Habitat: Epiphytic in premontane wet forest on the Caribbean slopes of Cordillera de Talamanca in Tapantí National Park, Costa Rica.

A species similar to L. johnsonii, L. tapantiensis can be distinguished vegetatively by the glabrous sheaths of the ramicaul (vs. hispidolous), and florally by the crenulate margins of the sepals (vs. smooth), the distinctly bilobed, obreniform petals with the two lobes separated by a small, rounded apicule (vs. subentire, narrowly triangular, without an apiculus), the lip provided with blades that are papillose at apex (vs. glabrous) and the color of the perianth. While in L. jobnsonii the sepals are yellow, sometimes with the tails' 
apices tinged with red, and the petals and column purplered, in L. tapantiensis the dorsal sepal is suffused with purple-red along the midvein and the lateral ones suffused with the same color along the labellar side of the midvein, the petals are yellow, blotched with red on the proximal margins, the apex of the upper lobe violet, and the column is violet (Pupulin \& Bogarín 2012).

\section{ACKNOWLEDGEMENTS}

We acknowledge the scientific services of Costa Rican Ministry of Environment, Energy, and Telecommunication (MINAET) and its National System of Conservation Areas (SINAC) for issuing the collecting permits under which wild species treated in this paper were collected. Our collegue Daniel Jiménez kindly provided material and information. Eugenio García of Fundación Reserva Biológica Dúrika and Fabricio Carbonell of Parque Internacional La Amistad-Pacífico for granting access to the protected areas. The staff of AMES, CR, SEL, and USJ herbaria for granting access to the collections and facilities during this research. This research was enabled by the Projects 814-B2-161 "Hacia una moderna flora de orquídeas de Panamá" and 814-BO-052 "Flora Costaricensis: taxonomía y filogenia de la subtribu Pleurothallidinae (Orchidaceae) en Costa Rica," supported by the Vice Presidency of Research, University of Costa Rica.

\section{REFERENCES}

Ames, O. 1923. New or noteworthy Orchids. Schedulae Orchidianae 3: 1-27. Ames, O. \& Correll, D. S. 1952. Orchids of Guatemala. Fieldiana, Botany 26(1): i-xiii, 1-395.

Archila, M.F.L. 2001. Lepanthes de Guatemala: monografía del Género Lepanthes Sw. (Orchidaceae) para Guatemala. Editorial Kamar, Guatemala.
Hágsater, E. \& Soto Arenas, M. A. 2003. Orchids of Mexico. Icones Orchidacearum (Mexico) 5-6: i-xxii, t. 501-t. 700

Luer, C.A. 1986. Icones Pleurothallidinarum I. Systematics of the Pleurothallidinae (Orchidaceae). Monographs in Systematic Botany from the Missouri Botanical Garden 15: 1-81.

Luer, C.A. 1996. Icones Pleurothallidinarum XIV. Systematics of Draconanthes, Lepanthes subgenus Marsipanthes, and subgenus Lepanthes of Ecuador (Orchidaceae). Part Three: The genus Lepanthes subgenus Lepanthes in Ecuador. Monographs in Systematic Botany from the Missouri Botanical Garden 61: 1-255.

Mutis, J.C. 1969. Flora de la Real Expedición Botánica del Nuevo Reino de Granada: (1783-1816) / promovida y dirigida por José Celestino Mutis. publicada bajo los auspicios de los Gobiernos de España y de Colombia. Madrid and Bogotá, Institutos de Cultura Hispánica and Real Jardín Botánico de Madrid.

Pupulin, F. 2001. New taxa in Costa Rican Lepanthes (Orchidaceae). Harvard Papers in Botany. 6(1): 289-294.

Pupulin, F. 2007. Epidendra, the botanical databases of Jardín Botánico Lankester at the University of Costa Rica. Lankesteriana 7: 178-180.

Pupulin, F. \& Bogarín, D. 2012. Lepanthes novae Tapantienses. Orchid Digest 76(1): 20-29.

Schlechter, R. 1912. Orchidaceae novae et criticae. Decas XXVII-XXVIII Repertorium Specierum Novarum Regni Vegetabilis 10(254-256): 352-363. http://dx.doi.org/10.1002/fedr.19120102105.

Salazar, G. A. \& Soto Arenas, M. A. 1996. El género Lepanthes Sw. en México. Orquídea (Mexico City), n.s., 14: 1-231.

Thoerle, L. 2010. Lepanthes matisii: a new name for an orchid known for centuries. Orchid Digest 75(1): 24-31.

Associate Editor: Javier Fuertes Received: 23-IV-2012 Accepted: 14-VII-2014 